Article

\title{
Constructed Wetlands as Sustainable Technology for the Treatment and Reuse of the First-Flush Stormwater in Agriculture-A Case Study in Sicily (Italy)
}

\author{
Teresa Tuttolomondo ${ }^{1}$, Giuseppe Virga ${ }^{2, *}$, Mario Licata ${ }^{1, *}$, Claudio Leto ${ }^{1,2}$ \\ and Salvatore La Bella ${ }^{1}$ \\ 1 Department of Agricultural, Food and Forest Sciences, Università degli Studi di Palermo, \\ Viale delle Scienze 13, Building 4, 90128 Palermo, Italy; teresa.tuttolomondo@unipa.it (T.T.); \\ claudio.leto@unipa.it (C.L.); salvatore.labella@unipa.it (S.L.B.) \\ 2 Research Consortium for the Development of Innovative Agro-environmental Systems (CoRiSSIA), \\ Via della Libertà 203, 90143 Palermo, Italy \\ * Correspondence: giuseppe.virga@corissia.it (G.V.); mario.licata@unipa.it (M.L.)
}

Received: 14 August 2020; Accepted: 9 September 2020; Published: 11 September 2020

\begin{abstract}
This paper describes a case study that was carried out on a Sicilian company (Italy) dealing with separate waste collection and recycling of glass. The aims of this study were to evaluate the overall efficiency of a vertical subsurface flow system (VSSFs) constructed wetland (CW) operating for the treatment of first-flush stormwater and the effects of treated wastewater on the morphological and aesthetic characteristics of ornamental pepper and rosemary plants. The system had a total surface area of $46.80 \mathrm{~m}^{2}$ and was planted with common reed and giant reed. Wastewater samples were taken from October 2018 to July 2019 at the CW inlet and outlet for chemical-physical and microbiological characterization of the wastewater. Two separate experimental fields of rosemary and ornamental pepper were set up in another Sicilian location. Three sources of irrigation water, two accessions of rosemary and two varieties of ornamental pepper were tested in a split-plot design for a two-factor experiment. The results showed very high organic pollutant removal $\left(\mathrm{BOD}_{5} 75-83 \%\right.$, COD 65-69\%) and a good efficiency of nutrients (TN 60-66\%) and trace metals (especially for $\mathrm{Cu}$ and $\mathrm{Zn}$ ) removal. Escherichia coli concentration levels were always lower than $100 \mathrm{CFU} 100 \mathrm{~mL}^{-1}$ during the test period. Irrigation water and plant habitus had significant effects on all the morphological and aesthetic characteristics of the plants. For both the crops, plants irrigated with freshwater and treated wastewater had greater growth and showed a better general appearance in comparison with plants irrigated with wastewater. The higher trace metal levels in the wastewater produced adverse effects on plant growth and reduced the visual quality of the plants. Our results suggest the suitability of a VSSFs constructed wetland for the treatment of first-flush stormwater and the reuse of treated wastewater for irrigation purposes, in accordance with legislation requirements concerning wastewater quality.
\end{abstract}

Keywords: first-flush stormwater; vertical subsurface flow system constructed wetland; wastewater reuse; sustainable agriculture; ornamental plants

\section{Introduction}

In urban areas, stormwater runoff has been recognized as a substantial contributor to water quality degradation due to high pollutants concentrations [1-3]. The qualitative characteristics of stormwater 
have been previously investigated and are greatly dependent on the type of surfaces the stormwater encounters, such as pavements, highways, roofs, parking lots and drains [3].

However, the concentration peak tends to vary for various pollutants during the same storm event and it has been demonstrated that pollutants concentrations are generally higher at an early stage of the rainfall event than in later stages [4-7]. This phenomenon has been named first-flush event and determined as a relatively high proportion of the total pollutants load of stormwater [8]. A number of studies have found, in fact, that the initial portion of a rainfall-runoff event is more polluted than the later portions in terms of nitrogen, phosphorus, trace metals, organic and particulate matter and polycyclic aromatic hydrocarbons, in particular [3,7-11].

First-flush stormwater (FFSW) has been investigated all over the world and its effects have been assessed both in temperate and tropical climates, using various methodologies [12-15]. As stated by various authors $[5,10,16-18]$, pollutants in a first-flush event tend to vary in qualitative and quantitative terms due to the fact that this phenomenon is greatly affected by various factors such as rainfall intensity and duration, watershed area, impervious area and previous dry weather conditions.

However, considering the ecological aspects, it is possible to sustain that FFSW can represent a dangerous source of contaminants for the environment and an excess of nutrients and trace metals in this source of water, for example, can result in eutrophication of downstream water bodies and pollution of aquatic ecosystems and soil [19-21]. In urban areas in particular, industrial activities produce a large amount of nutrients, salts and heavy metals which can accumulate on the rough earth surface, pavements and roofs during non-rainy days. When intense rainfall events occur, FFSW is generated, and subsequently, polluted water is discharged into the surrounding environment producing negative consequences. The effects on natural waterbodies can be most severe and the pollution degree of these ecosystems can be variable, depending on various factors such as land use type, traffic intensity and industrial density in the study area [22].

To control the quality of this source of water and reduce pollutant mass loading prior to discharge into receiving water bodies and soil, constructed wetland systems (CWs) can represent one of the best management practices for urban and industrial areas due to their intrinsic characteristics. They are green infrastructure technologies which provide many attributes able to remediate contaminants of various types of wastewaters, such as agricultural, domestic, industrial and municipal wastewaters, due to a plurality of treatments including biological, chemical and physical processes [3,23,24]. In particular, CWs areas offer the advantages of water storage and peak flow attenuation, nutrient cycling and uptake, heavy metals sequestration and removal of organic compounds together with other benefits, such as recreational facilities, in addition to functioning as a wildlife habitat [3,25-28]. In recent years, CWs have been also used for the treatment of stormwater runoff and a number of studies have described the CWs performance in terms of pollutants removal efficiency [3,29-32]. Various authors highlight, for example, that $\mathrm{CW}$ performance in treating stormwater is generally a function of the hydraulic characteristics of the system, which, in turn, are a function of storm intensity, runoff volume and CW size [3,33].

However, few studies [8-33] have investigated the reuse of treated stormwater for various applications, including irrigation. In semi-arid climate conditions, such as in southern Mediterranean countries, the reuse of unconventional water resources is a strategic topic for sustainable agriculture due to the fact that it represents an alternative to freshwater (FW), traditionally used in crop irrigation. As reported in various studies carried out in this area [34-40], the reuse of various types of treated wastewater (TWW) from CWs allows us to satisfy the water demand in irrigated agriculture whilst leading to significant savings in FW. Most of these studies have considered both horticultural and open-field crops and have focused on the effects of TWW on the morphological and yield parameters of these plants. However, few studies have been carried out on ornamental crops, which could be irrigated with TWW and used in urban green areas due to their high aesthetic and functional features.

In Italy, the reuse of TWW is regulated by Legislative Decree no. 152/2006 but it does not report specific guidelines on the treatment and reuse of stormwater runoff, assigning the regions the task of 
regulating control themselves. More specifically, Sicily (Italy) does not have a consistent regulation unlike many Italian regions.

The aims of this study were: (i) to evaluate the pollutants removal efficiency of a vertical subsurface flow system constructed wetland (VSSFs CW) used to treat FFSW which was built in an industrial plant for separate waste collection and recycling of glass in Sicily (Italy); (ii) to assess the effects of irrigation using treated first-flush stormwater (TFFSW) comparing irrigation with FFSW and FW on the morphological and aesthetic characteristics of rosemary (Rosmarinus officinalis L.) and ornamental pepper (Capsicum annuum L.) plants.

\section{Materials and Methods}

\subsection{Experimental Sites}

The study was initially carried out from 2018 to 2019 on a VSSFs CW (ExpA_1 code) that was built within the industrial area of a Sicilian company dealing with separate waste collection and glass recycling, in the west of Sicily (Marsala, $20 \mathrm{~m}$ a.s.l., $37^{\circ} 49^{\prime} 20^{\prime \prime} 28 \mathrm{~N}, 12^{\circ} 29^{\prime} 25^{\prime \prime} 80 \mathrm{E}$ ). The company is also the leader in the treatment of various type of wastes, such as metals, plastic and wood, and in management of hazardous wastes. According to the Köppen-Geiger climate classification [41], the location is characterized by a warm temperate Mediterranean climate with dry and hot summers. Annual average rainfall is approximately $450 \mathrm{~mm}$, mainly distributed between October and April. With reference to time series $1982-2012$, the annual average temperature was $17.70{ }^{\circ} \mathrm{C}$, average maximum temperature was $21.60^{\circ} \mathrm{C}$ and average minimum temperature was $13.80^{\circ} \mathrm{C}$.

In 2019, two separate experimental fields of rosemary and ornamental pepper were set up at the "Orleans" experimental farm (ExpA_2 code) (Palermo, $31 \mathrm{~m}$ a.s.l., $38^{\circ} 06^{\prime} 26.2^{\prime \prime} \mathrm{N}, 13^{\circ} 20^{\prime} 56.0^{\prime \prime} \mathrm{E}$ ) at the University of Palermo, northwest Sicily. The climate of the area is Mediterranean with mild, humid winters and hot, dry summers [41]. With reference to time series 1982-2012, the average annual temperature was $18.40^{\circ} \mathrm{C}$, with average minimum and maximum temperatures of 14.80 and $21.70{ }^{\circ} \mathrm{C}$, respectively. Annual average rainfall was approximately $600 \mathrm{~mm}$.

\subsection{VSSFs CW Test Site}

The VSSFs CW (Figure 1) was built in 2018 and located downhill from the existing wastewater pretreatment plant within the industrial area.
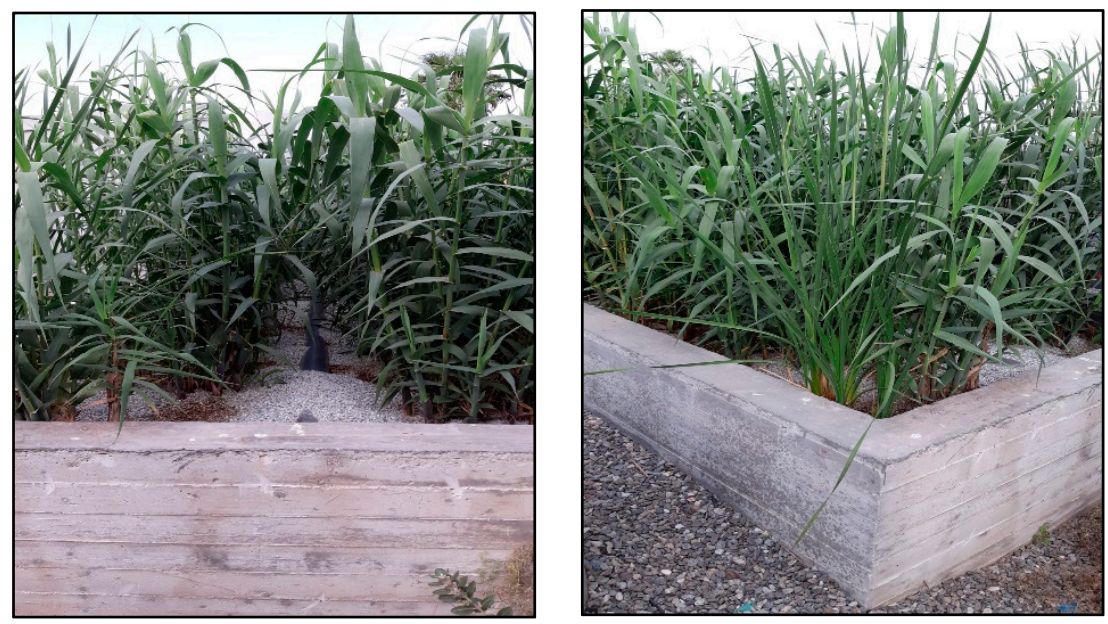

Figure 1. An overview of the vertical subsurface flow system (VSSFs) constructed wetland (CW) at ExpA_1.

The system included 1 unit, $26.0 \mathrm{~m}$ long and $1.80 \mathrm{~m}$ wide, providing a total surface filter bed area of $46.80 \mathrm{~m}^{2}$. The floor and walls of the unit were made of concrete and evenly lined with sheets 
of high-density polyethylene geomembrane which were covered with a layer of nonwoven fabric. Filter bed depth was $0.90 \mathrm{~m}$ to allow for greater root development and to create a larger rhizosphere. The slope was $1 \%$, needed to obtain regular flow. The unit was filled with three different layers of washed substrate of silica quartz river gravel (Si 30.28\%; Al 5.33\%; Fe 7.10\%; Ca 3.03\%; Mg 1.10\%), of which the top layer was 3-8 $\mathrm{mm}$, the intermediate layer was of $8-16 \mathrm{~mm}$ and the bottom layer was 16-30 mm in size. In 2018, common reed [Phragmites australis (Cav.) Trin. ex Steudel] and giant reed (Arundo donax L.) plants were collected from natural wetland areas near the plant site and the rhizomes were used for propagation in a small nursery at a constant moisture level. The rooted rhizomes were planted in the CW unit in March 2018 at a density of 4 rhizomes $\mathrm{m}^{-2}$ for each species; a polyculture system was then established in the CW.

The layout of the system for the treatment of FFSW is shown in Figure 2.

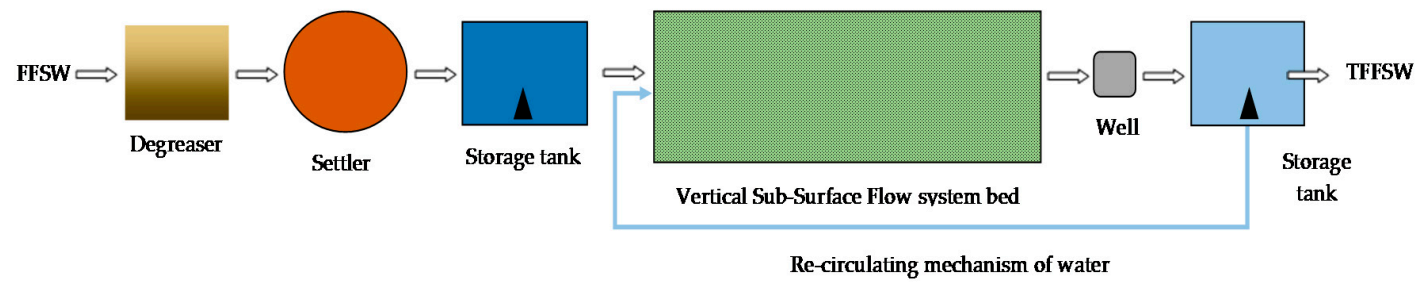

Figure 2. Layout of the first-flush stormwater (FFSW) treatment plant at ExpA_1.

In particular, both flotation and settling processes were carried out inside a degreaser. The FFSW was subsequently fed into a sedimentation tank to remove suspended solids and was then collected in a $30 \mathrm{~m}^{3}$ initial storage tank equipped with a submerged electric pump. The pretreated FFSW was pumped into the VSSFs CW unit and distributed vertically from the top of the unit. Two parallel polyvinyl-chloride perforated distribution pipes with an internal diameter of $120 \mathrm{~mm}$ were used to ensure even distribution of the wastewater throughout the filter bed section; these pipes were placed at $0.90 \mathrm{~m}$ distance. The homogeneous distribution of the effluent was ensured through a timer-controlled pumping system. In the VSSFs CW, FFSW was fed intermittently and, as a result, the system operated by cyclic flooding and draining. TFFSW was collected using a perforated drainage pipe system, placed at the bottom of the filter bed and then conducted downhill into a $15 \mathrm{~m}^{3}$ final storage tank. It was also equipped with a submerged electric pump to provide a re-circulating mechanism of water from the bottom to the top of the VSSFs CW during summer and to avoid the death of the plants due to a possible lack of rainfall. The $\mathrm{CW}$ unit operated under a hydraulic loading rate (HLR) of $13 \mathrm{~cm} \mathrm{day}^{-1}$ and a hydraulic retention time (HRT) of 7 day.

Concerning TFFSW management, it was generally dispersed into the surrounding soil using a subsurface irrigation system connected to the final storage tank. However, during 2019, FFSW and TFFSW were partly used to irrigate ornamental pepper and rosemary plants.

\subsection{FFSW Analysis}

Wastewater samples were taken from October 2018 to July 2019. Sampling campaigns were divided into two periods: the first period (I) ranged from October 2018 to February 2019, while the second period (II) ranged from March to July 2019. For an accurate assessment of the VSSFs CW, during the two periods, a total of 11 sampling days were selected where rainfall intensity was higher than $10 \mathrm{~mm} \mathrm{~d}^{-1}$. Samples were taken at the early part of an intense storm event. Total samples amounted to 22. The samples were collected at the inflow $(0 \mathrm{~m})$ and outflow $(26 \mathrm{~m})$ of the $\mathrm{CW}$ unit. An amount of $1 \mathrm{~L}$ of wastewater was collected from each of the two points at each sampling. The influent sample was collected at the mouth of the initial storage tank, while the effluent sample was taken from a TFFSW monitoring well. The influent and effluent samples were instantaneous samples.

The $\mathrm{pH}$, dissolved oxygen (DO), electrical conductivity (EC) and temperature (T) were determined at the time of sample collection, directly on site, using a portable Universal meter (Multiline WTW P4). 
Using Italian water analytical methods [42], total suspended solids (TSS), biochemical oxygen demand $\left(\mathrm{BOD}_{5}\right)$, chemical oxygen demand $(\mathrm{COD})$, total nitrogen $(\mathrm{TN})$, ammonium nitrogen $\left(\mathrm{NH}_{4}-\mathrm{N}\right)$, nitrate nitrogen $\left(\mathrm{NO}_{3}-\mathrm{N}\right)$, total phosphorus $(\mathrm{TP})$, trace metals $(\mathrm{Al}$, total $\mathrm{Cr}, \mathrm{Cu}, \mathrm{Fe}, \mathrm{Ni}, \mathrm{Pb}$ and $\mathrm{Zn}$ ) and polycyclic aromatic hydrocarbons (PAHs) were determined. Escherichia coli concentrations were assessed by membrane filter methods, based on standard methods for water testing [43]. Removal efficiency (RE) of the VSSFs CW was based on pollutant concentrations and calculated according to International Water Association guidelines [44]:

$$
\mathrm{RE}=\frac{\left(\mathrm{C}_{\mathrm{i}}-\mathrm{C}_{0}\right)}{\mathrm{C}_{\mathrm{i}}}
$$

where $C_{i}$ and $C_{0}$ are the mean concentrations of the pollutants in the influent and effluent.

\subsection{Rosemary Experimental Field}

Two rosemary accessions (RSM code) were selected from 10-year-old mother plants of Rosmarinus officinalis L. located in a collection field. The selection was made on the basis of the different growth habitus of the accessions, which was erect for RSM_1 and prostrate for RSM_2. On 14 January 2019, each accession was propagated through stem cuttings which were obtained from apical plant parts $6 \mathrm{~cm}$ long. Cuttings were treated with naphthalenacetic acid $(0.50 \%)$ and then rooted in an uncovered cold greenhouse. On 22 March 2019, plantlings were transplanted into $16 \mathrm{~cm}$ diameter pots using a mixed substrate made with universal potting soil (67\%) and perlite (33\%). The pots were placed on mulched soil with black polypropylene sheets. An amount of $3 \mathrm{~kg} \mathrm{~m}^{-3}$ of nitrogen $(\mathrm{N})$, phosphorus $(\mathrm{P})$ and potassium (K) slow-release fertilizer with magnesium $(\mathrm{Mg})$ and sulfur $(\mathrm{S})$ 15-9-15(+2+16) was distributed before transplanting. Subsequently, a number of fertigations, during the growth stages of rosemary plants, were carried out using 1\%o water-soluble fertilizer N-P-K(Mg) 15-10-15(+2)+(trace elements). The experimental field of rosemary (Figure 3) was equipped with three drip irrigation systems, one for each source of irrigation water used in the study (FW, TFFSW and FFSW). During the growing season of rosemary plants, moisture levels in the pot substrate were evaluated by measuring the substrate water content percentage, in accordance with Yadav et al. [45]. The water percentage in the substrate was determined at $48 \mathrm{~h}$ after the pots were watered to the field capacity of the substrate. Three substrate samples of $50 \mathrm{~g}$ each were collected, randomly, from pots for each irrigation water treatment, oven dried at $100{ }^{\circ} \mathrm{C}$ until constant weight and reweighed. The substrate water content percentage was calculated using the formula [45]:

$$
\text { substrate water content }=\frac{(\text { watered substrate weight }- \text { dried substrate weight })}{\text { watered substrate weight }} \times 100 .
$$

Nutrients and water leaching from pots were collected in a dish placed under each pot and the leachate was returned to the substrate before the irrigation water was applied.
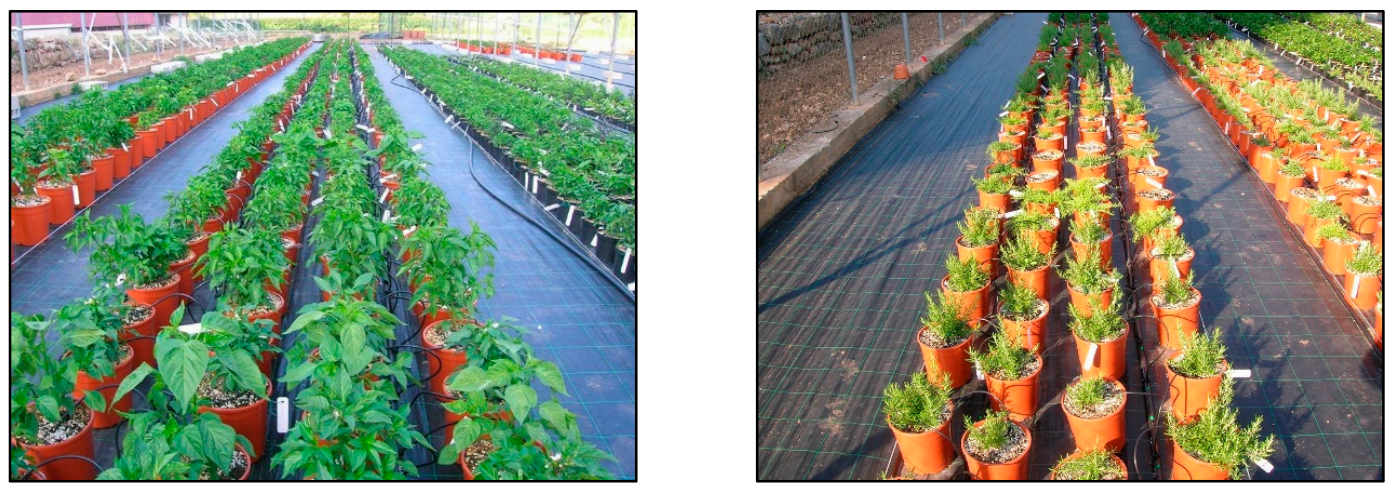

Figure 3. A view of the rosemary experimental field. 


\subsection{Ornamental Pepper Experimental Field}

Two ornamental pepper varieties (PPR code) were selected from a native germplasm collection of Capsicum annuum L. at the "Orleans" experimental farm. PPR_1 had an erect habit, while PPR_2 showed a pendant habit. The date of sowing was 6 March 2019. Expanded polystyrene seeding trays were used and seeds were covered by vermiculite as the substrate. An amount of $3 \mathrm{~kg} \mathrm{~m}^{-3}$ of N-P-K 15-9-15(+2+16) was distributed before transplanting. A number of fertigations, using water-soluble fertilizer N-P-K 20-20-20(+chelated minerals) were carried out starting from the development of the first true leaf. On 15 May 2019, plantlings were transplanted into $16 \mathrm{~cm}$ diameter pots using a mixed substrate made with universal potting soil $(67 \%)$ and perlite $(33 \%)$. The pots were placed on mulched soil with black polypropylene sheets in an uncovered cold greenhouse. The amount and types of fertilizers and the timing and frequency of fertilizers application were identical to those used for rosemary cultivation. The experimental field of ornamental pepper (Figure 4) was also equipped with three drip irrigation systems, one for each source of irrigation water used in the study (FW, TFFSW and FFSW). Irrigation was carried out using the same procedure as [45], previously described for rosemary plants.
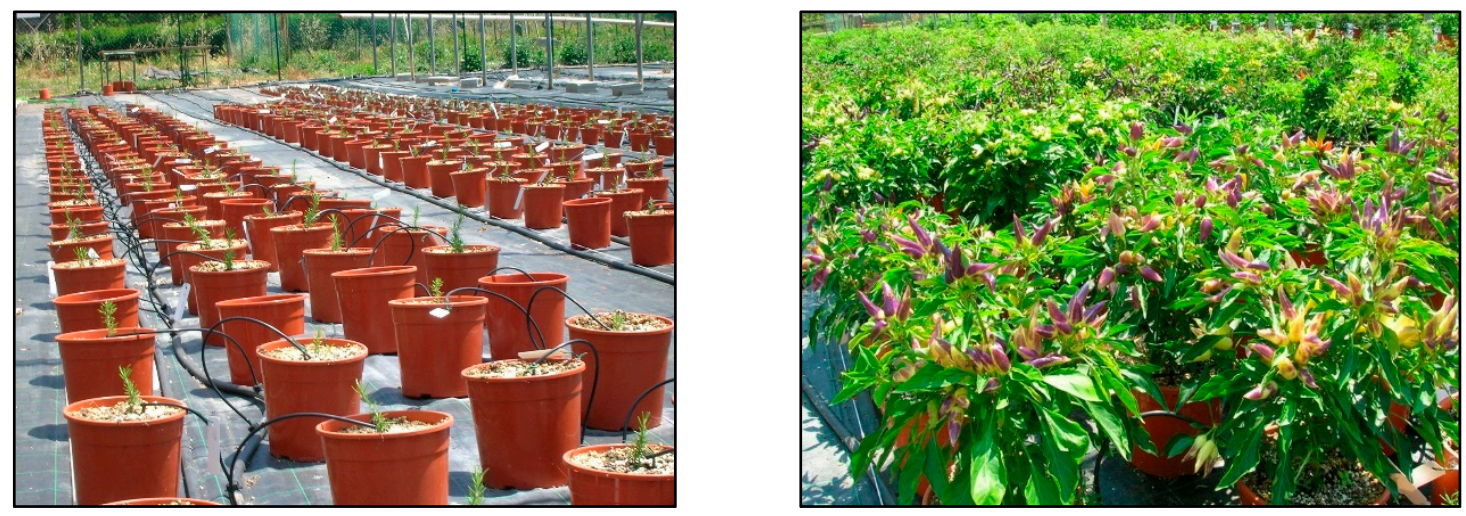

Figure 4. A view of ornamental pepper experimental field.

\subsection{Morphological and Aesthetic Characteristics of the Plants}

The morphological and aesthetic characteristics determined for rosemary were: plant height, plant diameter, number (no.) of primary and secondary branches per plant, number of leaves per $\mathrm{cm}$ branch $^{-1}$ and general appearance of the plants.

For ornamental pepper, the main parameters in the study were: plant height, plant diameter, number of fruits per plant and general appearance of the plants. In particular, for both of the species, general appearance of the plants was based on a 1 (=poorest or dead) to 9 (=outstanding or ideal) visual rating scale. Furthermore, the main growth stages of pepper plants were also recorded according to the extended $\mathrm{BBCH}$-scale [46]: flowering (first flower open), development of fruit (first fruit has reached typical size and form) and senescence (harvested product or plant death).

\subsection{Climatic Data}

Data on rainfall and temperature were collected from two meteorological stations, belonging to the Sicilian Agro-Meteorological Information Service [47]: station_1 was situated close to the pilot VSSFs CW and station_2 was located close to the two experimental fields. Both stations were equipped with an MTX datalogger (model WST1800, Padova, Italy) and various climate sensors. More specifically, a temperature sensor MTX (model TAM platinum PT100 thermo-resistance with anti-radiation screen, Padova, Italy) and a rainfall sensor MTX (model PPR with a tipping bucket rain gauge, Padova, Italy) provided data on average daily air temperature $\left({ }^{\circ} \mathrm{C}\right)$, total daily rainfall frequency $(\mathrm{d} \mathrm{mm}>1)(\%)$ and rainy days per year $(\mathrm{d} \mathrm{mm}>1)(\%)$. 


\subsection{Experimental Design and Statistical Analysis}

A split-plot design for a two-factor experiment was used with three replications. The main plot factor was irrigation water (IW) with three treatment levels: $\mathrm{IW}_{1}(\mathrm{FW}) ; \mathrm{IW}_{2}$ (TFFSW); and $\mathrm{IW}_{3}$ (FFSW). The subplot factor was plant habitus (PH) with two treatments levels. For rosemary, the levels were: $S_{1}$ (erect habit) and $S_{2}$ (prostrate habit). For ornamental pepper, the treatment levels were: $\mathrm{S}_{1}$ (erect habit) and $\mathrm{S}_{2}$ (pendant habit). Statistical analysis was performed using the package MINITAB 17 for Windows. Data were compared using analysis of variance. The difference between means was carried out using the Tukey test. For FW, FFSW and TFFSW, all the representative values were presented using mean \pm standard deviation calculations.

\section{Results and Discussion}

\subsection{Rainfall and Temperature Trends in the Experimental Site of the VSSFs CW}

Trends on air temperature and total rainfall are shown in Figure 5.

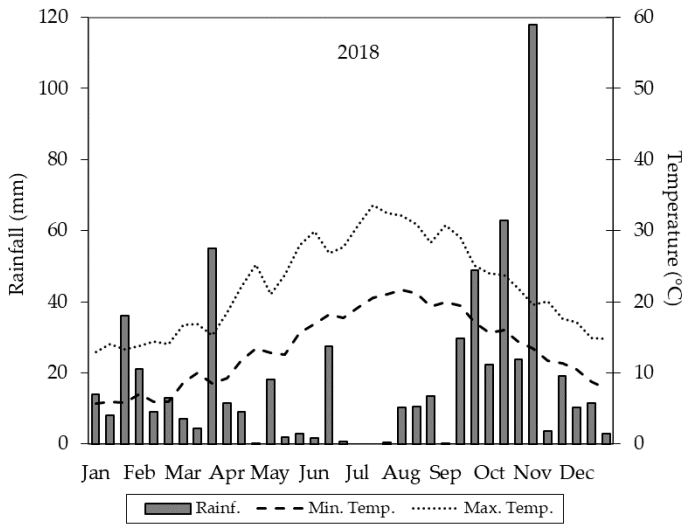

(a)

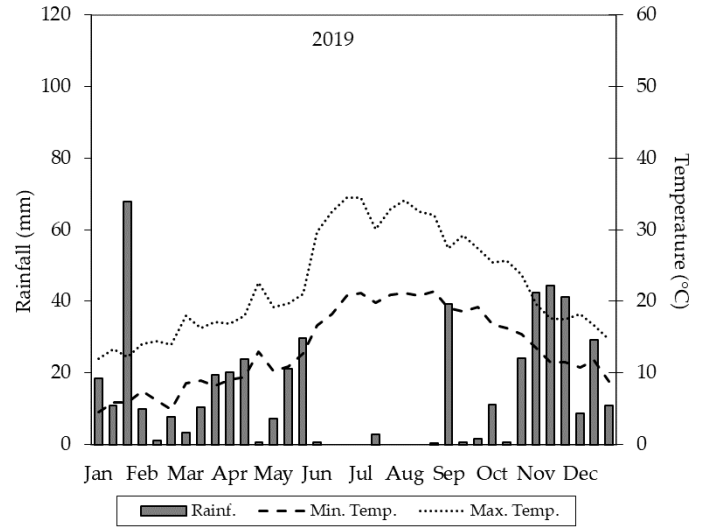

(b)

Figure 5. Rainfall and temperature trends during the test period in ExpA_1. Graph (a) refers to 2018, while graph (b) refers to 2019 .

In ExpA_1, average air temperature and rainfall trends were consistent with eleven-year averages, shown in Supplementary Table S1.

In both the years, maximum and minimum air temperatures increased from the beginning of March to the third 10-day period of August and decreased up to the end of December. The highest maximum air temperature $\left(34.13^{\circ} \mathrm{C}\right)$ was recorded in the first 10-day period of August 2019 and the lowest minimum air temperature $\left(4.47^{\circ} \mathrm{C}\right)$ was determined on the first 10-day period of January 2019. Total rainfall was $628 \mathrm{~mm}$ (2018) and $509 \mathrm{~mm}$ (2019). The highest rainfall levels (118 mm) occurred during the first 10-day period of November 2018. Rainy days were highly concentrated in the winter season. In the summer period, average monthly rainfall was $21 \mathrm{~mm}$ (2018) and $14 \mathrm{~mm}$ (2019). The highest treatment performance of the VSSFs CW was found from June to September when air temperatures, in particular, positively influenced plant growth and microbiological activities in the CW unit. Furthermore, during the autumn months, we observed a non-significant decrease in plant activity due to mild air temperatures. The favorable climate conditions allowed the plants to extend their vegetative cycle until the end of autumn, delaying the dormancy period and, consequently, their ability to remove pollutants from wastewater.

\subsection{Removal Efficiency of Pollutants in the VSSFs CW}

Data showing chemical-physical variations relating to FFSW are shown in Table 1. 
Table 1. Variation (VA) of $\mathrm{pH}$, temperature (T), electrical conductivity (EC) and dissolved oxygen (DO) in the VSSFs CW from October 2018 to July 2019. Average values ( \pm standard deviation) are shown $(n=18)$.

\begin{tabular}{ccccccc}
\hline Parameter & \multicolumn{2}{c}{ I Period } & \multicolumn{2}{c}{ II Period } \\
\hline & Inlet & Outlet & VA (\%) & Inlet & Outlet & VA (\%) \\
\hline $\mathrm{pH}$ & $7.67 \pm 0.15$ & $7.49 \pm 0.12$ & 2.33 & $7.74 \pm 0.07$ & $7.19 \pm 0.22$ & 6.98 \\
$\mathrm{~T}\left({ }^{\circ} \mathrm{C}\right)$ & $21.86 \pm 0.84$ & $21.00 \pm 1.06$ & 3.95 & $23.73 \pm 0.59$ & $22.98 \pm 1.20$ & 3.23 \\
$\mathrm{EC}\left(\mu \mathrm{cm}^{-1}\right)$ & $1299.56 \pm 133.2$ & $1161.56 \pm 176.2$ & 11.02 & $1319.54 \pm 75.7$ & $1123.45 \pm 75.2$ & 14.88 \\
$\mathrm{DO}\left(\mathrm{mg} \mathrm{L}^{-1}\right)$ & $1.31 \pm 0.18$ & $1.49 \pm 0.22$ & -13.66 & $1.35 \pm 0.16$ & $2.35 \pm 0.61$ & -73.68 \\
\hline
\end{tabular}

The $\mathrm{pH}$ value at the inlet of the VSSFs CW was moderately alkaline; however, at the outlet it was less alkaline, in accordance with other studies [34,48]. The decrease in the $\mathrm{pH}$ value has been previously explained [49] by the production of $\mathrm{CO}_{2}$ caused by the decomposition of plant residues in the substrate, by the removal of various wastewater components retained in the root area and by the nitrification of ammonia nitrogen. In our study, the FFSW average temperature at the inflow was $21.86{ }^{\circ} \mathrm{C}$ but it decreased through the system. The decrease in temperature at the outlet of the VSSFs $\mathrm{CW}$ was probably due to the fact that the system operated for most of the day under shady conditions. The EC variation was different in the two monitoring periods and it was higher $(14.25 \%)$ in period II due to the better climate conditions for plant growth. As reported by Kadlec et al. [44], despite the fact that the evapotranspiration process increased the solute concentration, the decrease in the EC value could be due to various factors, such as nutrients uptake by plants and microorganisms, and the adsorption by the roots, substrate and undecomposed plant residues. An increase in the DO value was found at the outlet of the system for both periods; the greater atmospheric aeration of the VSSFs determined a higher oxygen content in the $\mathrm{CW}$ that was exploited by aerobic bacteria to remove the organic and mineral pollutants of the FFSW.

With regard to pollutant removal levels, the main results are reported in Tables 2 and 3 and Figure 6.

Table 2. Main chemical and physical composition of the FFSW from the inflow and outflow of the VSSFs CW. Removal efficiency from October 2018 to July 2019. Average values ( \pm standard deviation) are shown $(n=22)$.

\begin{tabular}{|c|c|c|c|c|c|c|}
\hline \multirow[t]{2}{*}{ Parameter } & \multicolumn{3}{|c|}{ I Period } & \multicolumn{3}{|c|}{ II Period } \\
\hline & Inlet & Outlet & RE (\%) & Inlet & Outlet & RE (\%) \\
\hline TSS $\left(\mathrm{mg} \mathrm{L}^{-1}\right)$ & $17.60 \pm 4.56$ & $8.18 \pm 2.10$ & 50.84 & $28.60 \pm 0.98$ & $9.23 \pm 0.77$ & 67.58 \\
\hline $\mathrm{BOD}_{5}\left(\mathrm{mg} \mathrm{L}^{-1}\right)$ & $86.90 \pm 29.33$ & $20.18 \pm 2.35$ & 75.17 & $104.87 \pm 10.07$ & $16.84 \pm 2.45$ & 83.48 \\
\hline $\operatorname{COD}\left(\mathrm{mg} \mathrm{L}^{-1}\right)$ & $189.40 \pm 38.56$ & $70.80 \pm 13.70$ & 62.52 & $192.40 \pm 10.23$ & $59.80 \pm 2.38$ & 68.88 \\
\hline $\mathrm{TN}\left(\mathrm{mg} \mathrm{L}^{-1}\right)$ & $15.49 \pm 7.12$ & $6.32 \pm 2.81$ & 58.96 & $13.27 \pm 0.27$ & $4.43 \pm 0.29$ & 66.50 \\
\hline $\mathrm{NH}_{4}-\mathrm{N}\left(\mathrm{mg} \mathrm{L}^{-1}\right)$ & $6.39 \pm 7.24$ & $2.23 \pm 2.64$ & 65.82 & $5.58 \pm 1.13$ & $1.54 \pm 0.41$ & 72.30 \\
\hline $\mathrm{NO}_{3}-\mathrm{N}\left(\mathrm{mg} \mathrm{L}^{-1}\right)$ & $8.73 \pm 3.56$ & $9.51 \pm 3.78$ & -9.19 & $7.48 \pm 1.10$ & $8.59 \pm 1.35$ & -14.67 \\
\hline $\mathrm{TP}\left(\mathrm{mg} \mathrm{L}^{-1}\right)$ & $2.36 \pm 0.89$ & $1.86 \pm 0.71$ & 20.95 & $2.81 \pm 0.14$ & $1.89 \pm 0.16$ & 32.66 \\
\hline $\mathrm{Al}\left(\mathrm{mg} \mathrm{L}^{-1}\right)$ & $0.14 \pm 0.05$ & $0.12 \pm 0.04$ & 15.78 & $0.17 \pm 0.02$ & $0.13 \pm 0.01$ & 26.07 \\
\hline Tot $\mathrm{Cr}\left(\mathrm{mg} \mathrm{L}^{-1}\right)$ & $1.46 \pm 0.37$ & $1.14 \pm 0.27$ & 21.26 & $0.79 \pm 0.05$ & $0.38 \pm 0.06$ & 50.62 \\
\hline $\mathrm{Cu}\left(\mathrm{mg} \mathrm{L}^{-1}\right)$ & $0.36 \pm 0.16$ & $0.27 \pm 0.12$ & 24.56 & $0.32 \pm 0.01$ & $0.11 \pm 0.02$ & 65.92 \\
\hline $\mathrm{Fe}\left(\mathrm{mg} \mathrm{L}^{-1}\right)$ & $1.57 \pm 0.06$ & $1.35 \pm 0.05$ & 14.03 & $1.61 \pm 0.08$ & $1.00 \pm 0.04$ & 35.33 \\
\hline $\mathrm{Ni}\left(\mathrm{mg} \mathrm{L}^{-1}\right)$ & $0.27 \pm 0.15$ & $0.20 \pm 0.10$ & 24.01 & $0.24 \pm 0.05$ & $0.13 \pm 0.05$ & 45.82 \\
\hline $\mathrm{Pb}\left(\mathrm{mg} \mathrm{L}^{-1}\right)$ & $0.04 \pm 0.08$ & $0.04 \pm 0.03$ & 13.17 & $0.02 \pm 0.01$ & $0.01 \pm 0.01$ & 46.27 \\
\hline $\mathrm{Zn}\left(\mathrm{mg} \mathrm{L}^{-1}\right)$ & $0.11 \pm 0.06$ & $0.07 \pm 0.04$ & 37.73 & $0.08 \pm 0.02$ & $0.03 \pm 0.01$ & 62.66 \\
\hline PAHs (mg L $\left.{ }^{-1}\right)$ & $<0.001 \pm 0.01$ & $<0.001 \pm 0.00$ & 41.02 & $<0.001 \pm 0.02$ & $<0.001 \pm 0.01$ & 47.13 \\
\hline
\end{tabular}


Table 3. Escherichia coli concentration levels of the FFSW from the inflow and outflow of the VSSFs CW. Removal efficiency from October 2018 to July 2019. Average values ( \pm standard deviation) are shown $(n=18)$.

\begin{tabular}{ccccccc}
\hline Parameter & \multicolumn{3}{c}{ I Period } & \multicolumn{3}{c}{ II Period } \\
\hline & Inlet & Outlet & RE (\%) & Inlet & Outlet & RE (\%) \\
\hline Escherichia coli $\left(\mathrm{CFU} 100 \mathrm{~mL}^{-1}\right)$ & $578 \pm 0.27$ & $67 \pm 0.12$ & 88.44 & $417 \pm 0.56$ & $37 \pm 0.11$ & 91.12 \\
\hline
\end{tabular}

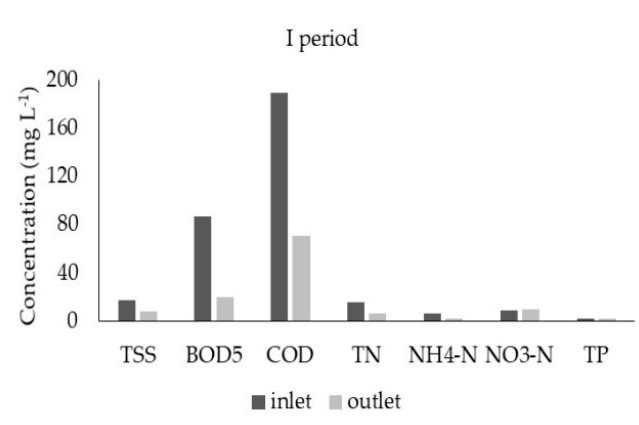

(a)

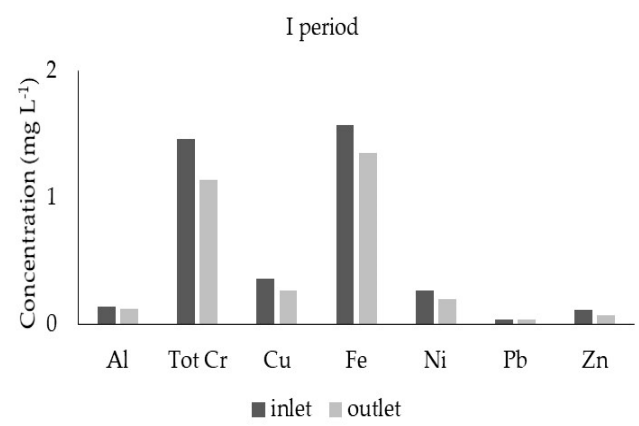

(c)

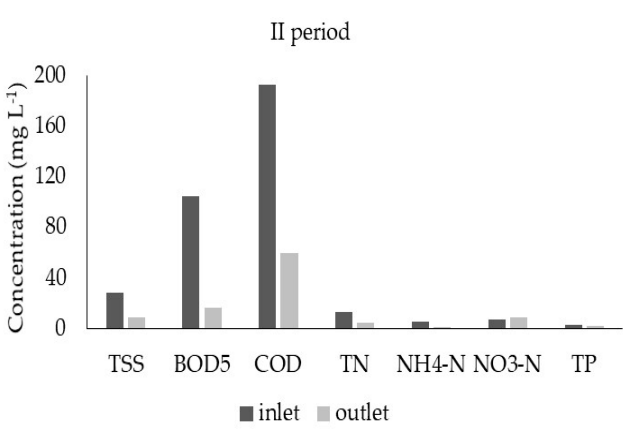

(b)

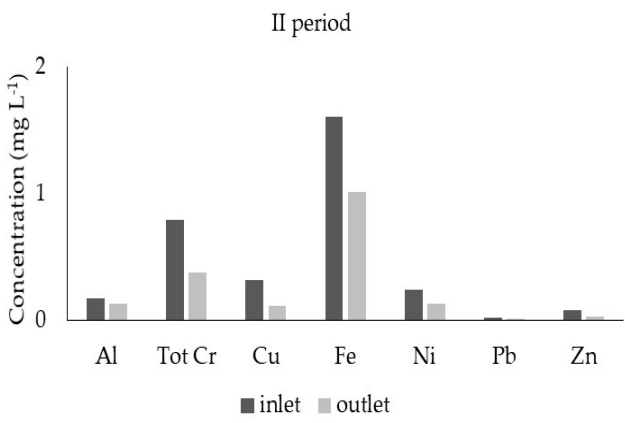

(d)

Figure 6. Average concentrations $\left(\mathrm{mg} \mathrm{L}^{-1}\right)$ for chemical parameters at the VSSFs CW inlet and outlet, during first-flush stormwater treatment (I and II monitoring periods). Graphs (a,b) refer to organic pollutants and macronutrients, while graphs $(\mathbf{c}, \mathbf{d})$ refer to trace elements.

At the inlet of the CW unit, pretreated FFSW pollutant concentrations were lower than prior to pretreatment. Intensive pretreatment (degreasing and settling), in fact, provided efficient treatment of the FFSW through physical, chemical and biological processes.

Average TSS RE was consistent with values found in the literature for VSSFs $[8,50,51]$ and can be described mainly by physical processes such as filtration and sedimentation in the substrate and plant roots, followed by aerobic and anaerobic microbial degradation inside the substrate [51,52]. Comparing the two periods of study, average TSS RE was different in period I compared to II and can be explained by plant growth during the year. As the CW unit was planted with two warm-season species, these species showed maximum growth during the spring and summer when air temperatures increased, and above- and belowground biomass values reached peak growth. In period II, from March to July, the matrix formed by the roots of the two species with the substrate trapped TSS and lowered the velocity of water more efficiently than during period I (in which vegetative activity decreased greatly due to lower air temperatures). This concept was well explained by Zurita et al. [51], who stated also that the presence of more species in a CW unit can increase TSS removal.

In our study, average $\mathrm{BOD}_{5}$ and $\mathrm{COD}$ concentrations in both periods were much lower at the outlet than at the inlet. However, similar to TSS results, average $\mathrm{BOD}_{5}$ and COD RE was higher during period II. In general, $\mathrm{BOD}_{5}$ and $\mathrm{COD}$ RE stayed within a range consistent with previous CW VSSFs studies using various types of wastewater $[8,50,51]$ and was probably influenced by the root growth of 
the two macrophytes. In accordance with other authors [51,53], the presence of two species provided a more efficient distribution of roots that favored the development of a microbial community around the root system and the substrate particles. Various bacteria, in fact, due to alternate aerobic and anaerobic conditions in the VSSFs, promoted degradation activities and determined a greater reduction in $\mathrm{BOD}_{5}$ and $\mathrm{COD}$ concentrations [54]. Furthermore, the higher root density increased the retention time of organic dissolved compounds and, consequently, improved $\mathrm{BOD}_{5}$ and $\mathrm{COD} \mathrm{RE}$ in the system.

As regards nitrogen, TN RE was higher in period II (66.50\%) compared to period I and fell within the removal percentage rates reported for the VSSFs CW in other studies $[23,25,51,55]$. Initial $\mathrm{NH}_{4}-\mathrm{N}$ concentration was relatively low and ranged between 0.06 and $18.01 \mathrm{mg} \mathrm{L}^{-1}$ (period I) and 4.15 and $6.81 \mathrm{mg} \mathrm{L}^{-1}$ (period II). However, it decreased greatly after treatment in both periods and $\mathrm{NH}_{4}-\mathrm{N}$ $\mathrm{RE}$ was $65.82 \%$ in period I and $72.30 \%$ in period II. The high $\mathrm{NH}_{4}-\mathrm{N}$ RE in the $\mathrm{CW}$ unit was the result of the higher rate of ammonium nitrification due to good aerobic conditions in the system. As stated by various authors [44], in a VSSFs, the major processes responsible for nitrogen removal are, in fact, nitrification/denitrification followed by plant uptake. During the nitrification process, in particular, ammonium $\mathrm{N}$ is oxidated to nitrate which is subsequently absorbed by plants or reduced to $\mathrm{N}$ gas during the denitrification process [48]. In our study, these processes occurred in the CW unit and contributed to $\mathrm{NH}_{4}-\mathrm{N} \mathrm{RE}$, although plant uptake and the denitrification process led to different nitrate removal rates. When observing, instead, the average $\mathrm{NO}_{3}-\mathrm{N}$ concentration in the influent, it was lower than $10 \mathrm{mg} \mathrm{L}^{-1}$ in both the study periods. However, unlike that found for $\mathrm{NH}_{4}-\mathrm{N} \mathrm{RE}$, the $\mathrm{NO}_{3}-\mathrm{N}$ concentration slightly increased in the effluent, thus producing negative $\mathrm{RE}$. Our results were in accordance with those of other authors $[50,51]$ who found that the VSSFs CW successfully removed ammonium $\mathrm{N}$ but limited denitrification occurred. This fact can be explained considering the unfavorable conditions for $\mathrm{NO}_{3}-\mathrm{N}$ removal due to high aerobic conditions in the VSSFs CW. As clearly explained by Abdelhakeem et al. [50], in a constructed wetland, as nitrate is mainly removed throughout the denitrification processes, anaerobic conditions (required for the onset of $\mathrm{NO}_{3}$ removal) are not fulfilled under the VSSFs CW. Consequently, as confirmed by Vymazal [25], the VSSFs offers good oxygen conditions for ammonium nitrification but unfavorable conditions for nitrate denitrification.

The data in Table 2 show low values for initial TP concentration and removal percentages in both the study periods. In particular, RE values ranged between 20.95\% (period I) and 32.66\% (period II) and were consistent with those found in the literature for many VSSFs [33,50,56]. However, the values of this study were much lower than those found by other authors $[51,57]$ who used substrates with different characteristics. In our research, the lower TP RE was mainly due to the physical characteristics of the gravel which was used as a medium. The literature highlights that the removal of phosphorus is highly dependent upon the type of substrate used [24] and the high $\mathrm{Ca}, \mathrm{Al}$ and Fe content in the substrate positively influences the TP RE. A number of studies were carried out in various countries in order to assess the effect of the substrate on TP removal in a VSSFs. In a study on the performance of a VSSFs CW under different operational conditions, the authors of [50] found that vermiculite media (25\%) removed significantly higher amounts of TP compared to gravel (14\%) due to marked adsorption of $\mathrm{P}$ by vermiculite particles. In another study [57], it was found that a mixture of a river sand and dolomitic limestone led to a TP RE of $45 \%$ in a VSSFs. The type of medium and its physical characteristics such as size and adsorption capacity are, thus, fundamental in order to lower TP concentrations in the effluent, independent of the phosphorus uptake by the plant roots.

Trace metals represent a substantial component of FFSW composition. As reported by Kadlec et al. [44], although some metals, such as chromium, copper, iron and zinc, are required for plant growth in trace quantities, these same metals can be toxic at higher concentrations. Moreover, other metals, such as cadmium and lead, can be toxic at even low concentrations. In our study, the removal efficiencies of trace metals mostly increased during period II but were found to be lower than the RE of other chemical parameters in the study. In general, in both periods, higher concentrations in the influent $\left(>1 \mathrm{mg} \mathrm{L}^{-1}\right)$ were recorded only for $\mathrm{Fe}$, while $\mathrm{Zn}$ and $\mathrm{Cu}$ showed higher RE values. 
It is interesting to note that during period II, the $\mathrm{Pb} \mathrm{RE}$ value (46.27\%) was appreciable, despite this element being present at a lower concentration. Our findings were compared with results from other studies and considerable differences were found. In a study carried out on a wetland constructed in the Sydney catchment, the authors of [58] found highly variable REs of trace metals from urban stormwater and reported $\mathrm{RE}$ values for $\mathrm{Cr}(67-84 \%), \mathrm{Cu}(56-86 \%), \mathrm{Pb}(44-89 \%), \mathrm{Zn}(33-87 \%)$ and $\mathrm{Ni}$ (72-76\%). In another study, conducted in experimental, temporarily flooded vertical-flow wetland filters treating urban wastewater runoff, a significant reduction in $\mathrm{Cu}(>95 \%)$ was recorded, while the Ni RE by the filter planted with common reed was found to be lower than that of the unplanted filter [59]. One study [44] highlighted the fact that the processes involved in trace metal removal in CWs are various and mainly depend on the vegetation, substrate and water. In particular, vegetation provides several actions, such as metal uptake and translocation, adsorption, organic decomposition and filtration. In our study, the effects of vegetation on trace metal removal were not investigated, however, it is reasonable to sustain that a polyculture system, similar to this study, may result in a higher metal RE than a monoculture system due to the different nutrients uptake potential of the various macrophytes and translocation in plant tissues.

PAHs examined in both periods were in very low concentrations $\left(<0.001 \mathrm{mg} \mathrm{L}^{-1}\right)$ and $\mathrm{RE}$ values were found to be similar in both the periods. The present study did not determine the PAHs concentration in plant tissues, but in the $\mathrm{CW}$ unit, the two macrophytes contributed greatly to PAH removal. This statement was confirmed by Ventura et al. [31], who affirmed that the interaction between plants and microorganisms positively influenced hydrocarbon degradation and improved the quality of wastewater in the effluent. However, although a number of studies $[31,60,61]$ highlighted that filtration and sedimentation represent the most relevant physical processes for PAH removal in a CW, the role of the macrophytes in removing PAHs is also fundamental, as demonstrated in a recent study [62] by the high concentrations of hydrocarbons found in above- and belowground biomass of Phragmites and Vetiver plants.

At a microbiological level (Table 3), Escherichia coli was selected as the main bacterial indicator in FFSW and was used to determine the disinfection efficiency of the VSSFs.

The VSSFs was particularly effective at reducing E. coli during the tests. Concentrations of E. coli in the effluent were always lower than $100 \mathrm{CFU} 100 \mathrm{~mL}^{-1}$ in both periods. Our results agreed with those reported by Ávila et al. [8], who found a higher reduction in E. coli in a VSSFs treating sewer wastewater and stormwater. The relevant removal efficiency of E. coli can be explained by a combination of physical, chemical and biological processes carried out by the plants, nematodes, virus and bacteria, also illustrated by Brix [63]. Furthermore, taking into consideration the physical and functional characteristics of the VSSFs, it is important to observe that the higher oxygen concentration in the VSSFs determined unfavorable conditions for E. coli survival, facilitated the production of a greater bacteria biofilm and promoted its removal [64].

In our research, the average values of the chemical and microbiological parameters of TFFSW at the outflow of the VSSFs CW were not all within the threshold values for Italian Legislative Decree 152/2006 regarding the reuse of TWW for irrigation and the discharge of TWW into soil (Table 4).

Table 4. Threshold values for Italian Legislative Decree no. 152/2006 concerning the chemical (mg L ${ }^{-1}$ ) and microbiological (CFU $100 \mathrm{~mL}^{-1}$ ) parameters of treated wastewater (TWW) for reuse in agricultural irrigation and discharge into soil.

\begin{tabular}{cccccccccccccc}
\hline & \multicolumn{10}{c}{ Chemical Parameters } \\
\cline { 2 - 16 } & TSS & BOD $_{\mathbf{5}}$ & COD & TN & TP & Al & Tot Cr & Cu & Fe & Ni & Pb & Zn \\
\hline TWW Reuse for Irrigation & 10 & 20 & 100 & 15 & 2 & 1 & 0.1 & 1 & 2 & 0.2 & 0.1 & 0.5 \\
\hline TWW Discharge into the Soil & 25 & 20 & 100 & 15 & 2 & 1 & 1 & 0.1 & 2 & 0.2 & 0.1 & 0.5 \\
\hline
\end{tabular}


Table 4. Cont.

\begin{tabular}{cc}
\hline & \multicolumn{2}{c}{ Microbiological Parameters } \\
\cline { 2 - 2 } & Escherichia coli \\
\hline TWW Reuse for Irrigation & $10(80 \%$ samples) and 100 (maximum value point) \\
\hline TWW Discharge into Soil & $\leq 5000$ \\
\hline
\end{tabular}

In particular, in both periods, average concentrations of total Cr in the TFFSW were higher than the Italian standard limits for irrigation reuse. Furthermore, average concentrations of E. coli were not always acceptable in legal terms, despite the high removal efficiency by the VSSFs. One study [44] highlighted that microbially mediated processes of oxidation followed by subsequent precipitation of trace metals are considered the most effective metal removal mechanism in a CW. Furthermore, the use of different retention times in the system can positively affect the removal rate of bacteria due to changes in aerobic/anaerobic conditions in the substrate. The need to adopt these solutions and to improve biological and physical processes is evident in order to increase the removal efficiency in a VSSFs CW.

\subsection{Irrigation Water Characteristics}

The chemical and microbiological characteristics of FW, TFFSW and FFSW used in the irrigation of rosemary and ornamental pepper plants are shown in Table 5 . The composition of the three sources of irrigation water varied greatly over the test period. In general, FFSW had, on average, higher $\mathrm{BOD}_{5}$, COD, TSS, N, P, K and trace metal levels than FW and TFFSW. When comparing the three sources of irrigation water from March to July, the lowest variations in nutrient concentration were found during the summer months. In this period, the growth of above- and belowground biomass of common reed and giant reed increased much more than in other seasons and significantly influenced the pollutant RE in the VSSFs CW; this contributed to reducing pollutant concentrations at the outflow. For example, when comparing the effluent TN concentration of the effluent between March and July, large decreases in nitrogen in TFFSW were observed, mainly due to the nitrification process and plant uptake.

Table 5. Chemical and microbiological composition of freshwater (FW), treated FFSW (TFFSW) and FFSW that were applied in the irrigation of ornamental pepper and rosemary plants.

\begin{tabular}{|c|c|c|c|}
\hline Parameter & FW & TFFSW & FFSW \\
\hline $\mathrm{pH}$ & $7.01 \pm 0.07$ & $7.25 \pm 1.01$ & $7.97 \pm 1.21$ \\
\hline $\mathrm{DO}\left(\mathrm{mg} \mathrm{L}^{-1)}\right.$ & Not available & $2.44 \pm 0.63$ & $1.42 \pm 0.14$ \\
\hline $\mathrm{EC}\left(\mu \mathrm{S} \mathrm{cm}^{-1}\right)$ & $255 \pm 1.24$ & $1112 \pm 55.12$ & $1813 \pm 42.11$ \\
\hline $\mathrm{BOD}_{5}\left(\mathrm{mg} \mathrm{L}^{-1}\right)$ & $1.35 \pm 0.04$ & $17.04 \pm 2.12$ & $141.11 \pm 11.21$ \\
\hline $\operatorname{COD}\left(\mathrm{mg} \mathrm{L}^{-1}\right)$ & $1.99 \pm 0.02$ & $60.21 \pm 1.99$ & $272.41 \pm 9.23$ \\
\hline $\operatorname{TSS}\left(\mathrm{mg} \mathrm{L}^{-1}\right)$ & Not detected & $9.46 \pm 0.61$ & $61.21 \pm 1.10$ \\
\hline $\mathrm{TN}\left(\mathrm{mg} \mathrm{L}^{-1}\right)$ & Not detected & $4.12 \pm 0.21$ & $34.11 \pm 0.12$ \\
\hline $\mathrm{NH}_{4}-\mathrm{N}\left(\mathrm{mg} \mathrm{L}^{-1}\right)$ & Not detected & $1.42 \pm 0.12$ & $8.12 \pm 1.16$ \\
\hline $\mathrm{NO}_{3}-\mathrm{N}\left(\mathrm{mg} \mathrm{L}^{-1}\right)$ & $0.42 \pm 0.11$ & $8.86 \pm 1.21$ & $23.12 \pm 1.54$ \\
\hline $\mathrm{TP}\left(\mathrm{mg} \mathrm{L}^{-1}\right)$ & $0.61 \pm 0.21$ & $1.79 \pm 0.08$ & $5.12 \pm 0.23$ \\
\hline $\mathrm{K}\left(\mathrm{mg} \mathrm{L}^{-1}\right)$ & $3.01 \pm 0.12$ & Not available & Not available \\
\hline SAR (meq L $\left.{ }^{-1}\right)$ & $1.01 \pm 0.23$ & Not available & Not available \\
\hline $\mathrm{Al}\left(\mathrm{mg} \mathrm{L}^{-1}\right)$ & Not available & $0.15 \pm 0.01$ & $0.25 \pm 0.04$ \\
\hline Tot $\mathrm{Cr}\left(\mathrm{mg} \mathrm{L}^{-1}\right)$ & Not available & $0.32 \pm 0.04$ & $0.78 \pm 0.09$ \\
\hline $\mathrm{Cu}\left(\mathrm{mg} \mathrm{L}^{-1}\right)$ & Not available & $0.13 \pm 0.01$ & $0.51 \pm 0.01$ \\
\hline $\mathrm{Fe}\left(\mathrm{mg} \mathrm{L}^{-1}\right)$ & Not available & $1.09 \pm 0.04$ & $1.95 \pm 0.11$ \\
\hline $\mathrm{Ni}\left(\mathrm{mg} \mathrm{L}^{-1}\right)$ & Not available & $0.17 \pm 0.03$ & $0.44 \pm 0.02$ \\
\hline $\mathrm{Pb}\left(\mathrm{mg} \mathrm{L}^{-1}\right)$ & Not available & $0.01 \pm 0.01$ & $0.13 \pm 0.01$ \\
\hline $\mathrm{Zn}\left(\mathrm{mg} \mathrm{L}^{-1}\right)$ & Not available & $0.03 \pm 0.05$ & $0.14 \pm 0.03$ \\
\hline PAHs $\left(\mathrm{mg} \mathrm{L}^{-1}\right)$ & Not available & $<0.001 \pm 0.01$ & $<0.001 \pm 0.02$ \\
\hline E. coli $\left(\mathrm{CFU} 100 \mathrm{~mL}^{-1}\right)$ & Not detected & $31 \pm 0.06$ & $816 \pm 0.62$ \\
\hline
\end{tabular}


In arid and semi-arid regions, irrigation of plants with a treated effluent represents a sustainable practice and can be a means of managing FW shortages. In this scenario, the quality of the treated effluent is an important issue to assess when using a treated effluent in the irrigation of ornamental plants. The relative richness in nutrients, such as nitrogen, phosphorus, potassium and organic matter, increases the qualitative characteristics of the effluent, these nutrients being essential for plant growth and physiological processes within the plants. For ornamental pepper and rosemary in particular, some authors $[65,66]$ reported that the TWW application increased plant height and plant biomass compared with the FW application. Others have focused on the importance of TWW quality in the irrigation of horticultural and open-field crops and the majority of studies agree with the fact that a high nutrients content in TWW is fundamental in order to increase plant growth and yield.

\subsection{Temperature Trend in the Experimental Site of Ornamental Crops}

Trends in air temperatures are shown in Figure 7.

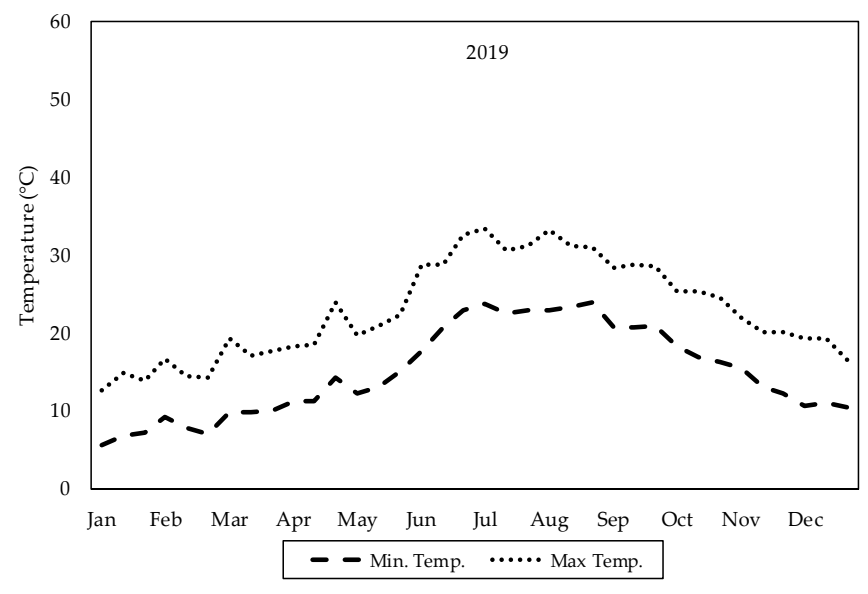

Figure 7. Temperature trend during the test period in ExpA_2.

In ExpA_2, the average air temperature trend was consistent with eleven-year averages (Supplementary Table S2).

When considering the growth stages of ornamental pepper and rosemary plants, from January to December, the air temperature was $19.5^{\circ} \mathrm{C}$ on average. Temperatures increased from March to the second 10-day period in July. The highest minimum and maximum air temperatures were 23.73 and $33.36^{\circ} \mathrm{C}$, respectively, and the lowest minimum and maximum air temperatures were 5.64 and $12.59^{\circ} \mathrm{C}$. In particular, the average air temperature, during the summer, positively influenced the phenological stages of the plants.

\subsection{Effects of Source of Irrigation Water and Type of Plant Habit on Rosemary Plants}

Data regarding the morphological and aesthetic characteristics of rosemary plants, under the influence of source of irrigation water and type of plant habitus, over the 2019 growing season, are shown in Table 6.

Irrigation water and plant habitus had significant effects on all the parameters in the study. Results revealed also that the interactions between the main factors were significant for all the parameters.

In general, the growth cycle length of the rosemary accessions was found to be close to 120 days on average (data not shown). 
Table 6. Morphological and aesthetic characteristics of erect and prostrate rosemary plants irrigated with FW, TFFSW and FFSW.

\begin{tabular}{|c|c|c|c|c|c|c|c|}
\hline Treatment & Plant Height (cm) & Plant Diameter (cm) & Plant Height/Diameter & $\begin{array}{l}\text { No. Primary Branches } \\
\text { (per Plant) }\end{array}$ & $\begin{array}{l}\text { No. Secondary Branches } \\
\text { (per Plant) }\end{array}$ & $\begin{array}{c}\text { No. Leaves } \\
\text { (per cm } \text { Branch }^{-1} \text { ) }\end{array}$ & $\begin{array}{c}\text { General Appearance } \\
(1-9)\end{array}$ \\
\hline \multicolumn{8}{|c|}{ Irrigation Water (IW) } \\
\hline $\mathrm{IW}_{1}$ & $15.97 \mathrm{a}$ & $23.38 \mathrm{a}$ & $0.67 \mathrm{a}$ & $14.73 \mathrm{a}$ & $43.99 \mathrm{a}$ & $12.18 \mathrm{a}$ & $4.26 \mathrm{a}$ \\
\hline $\mathrm{IW}_{2}$ & $15.73 \mathrm{a}$ & $24.15 \mathrm{a}$ & $0.64 \mathrm{a}$ & $13.93 \mathrm{a}$ & $43.59 \mathrm{a}$ & $12.61 \mathrm{a}$ & $4.68 \mathrm{a}$ \\
\hline $\mathrm{IW}_{3}$ & $12.61 \mathrm{~b}$ & $19.46 \mathrm{~b}$ & $0.62 \mathrm{a}$ & $10.87 \mathrm{~b}$ & $36.95 \mathrm{~b}$ & $9.55 \mathrm{~b}$ & $3.08 \mathrm{~b}$ \\
\hline \multicolumn{8}{|c|}{ Plant Habitus (PH) } \\
\hline $\mathrm{PH}_{1}$ & $19.27 \mathrm{a}$ & $26.82 \mathrm{a}$ & $0.72 \mathrm{a}$ & $16.18 \mathrm{a}$ & $65.36 \mathrm{a}$ & $8.95 \mathrm{~b}$ & $5.17 \mathrm{a}$ \\
\hline $\mathrm{PH}_{2}$ & $10.26 \mathrm{~b}$ & $17.84 \mathrm{~b}$ & $0.57 \mathrm{~b}$ & $10.17 \mathrm{~b}$ & $17.65 \mathrm{~b}$ & $13.94 \mathrm{a}$ & $2.84 \mathrm{~b}$ \\
\hline \multicolumn{8}{|c|}{ Irrigation Water $\times$ Plant Habitus } \\
\hline $\mathrm{IW}_{1} \times \mathrm{PH}_{2}$ & $11.16 \mathrm{c}$ & $19.40 \mathrm{c}$ & $0.57 \mathrm{~cd}$ & $12.30 \mathrm{bc}$ & $19.42 \mathrm{c}$ & $14.53 \mathrm{a}$ & $3.03 \mathrm{bc}$ \\
\hline $\mathrm{IW}_{2} \times \mathrm{PH}_{1}$ & $19.80 \mathrm{a}$ & $29.63 \mathrm{a}$ & $0.67 \mathrm{abc}$ & $17.33 \mathrm{a}$ & $68.76 \mathrm{a}$ & $9.90 \mathrm{c}$ & $6.16 \mathrm{a}$ \\
\hline $\mathrm{IW}_{2} \times \mathrm{PH}_{2}$ & $11.66 \mathrm{c}$ & $18.66 \mathrm{c}$ & $0.62 \mathrm{bcd}$ & $10.53 \mathrm{c}$ & $18.41 \mathrm{c}$ & $15.33 \mathrm{a}$ & $3.20 \mathrm{bc}$ \\
\hline $\mathrm{IW}_{3} \times \mathrm{PH}_{1}$ & $17.26 \mathrm{~b}$ & $23.46 \mathrm{~b}$ & $0.74 \mathrm{ab}$ & $14.06 \mathrm{~b}$ & $58.76 \mathrm{~b}$ & $7.13 \mathrm{~d}$ & $3.87 \mathrm{~b}$ \\
\hline $\mathrm{IW}_{3} \times \mathrm{PH}_{2}$ & $7.96 \mathrm{~d}$ & $15.46 \mathrm{~d}$ & $0.51 \mathrm{~d}$ & $7.67 \mathrm{~d}$ & $15.13 \mathrm{c}$ & $11.97 \mathrm{~b}$ & $2.30 \mathrm{c}$ \\
\hline
\end{tabular}

Means followed by the same letter are not significantly different for $p \leq 0.05$ according to the test of Tukey. 
When considering the morphological parameters, plant growth was greater in FW- and TFFSW-irrigated plants than in FFSW-irrigated plants. Differences in plant height with respect to the source of irrigation water were significant during the test period. In particular, FW- and TFFSW-irrigated plants were taller than FFSW-irrigated plants, on average (Figure 8).

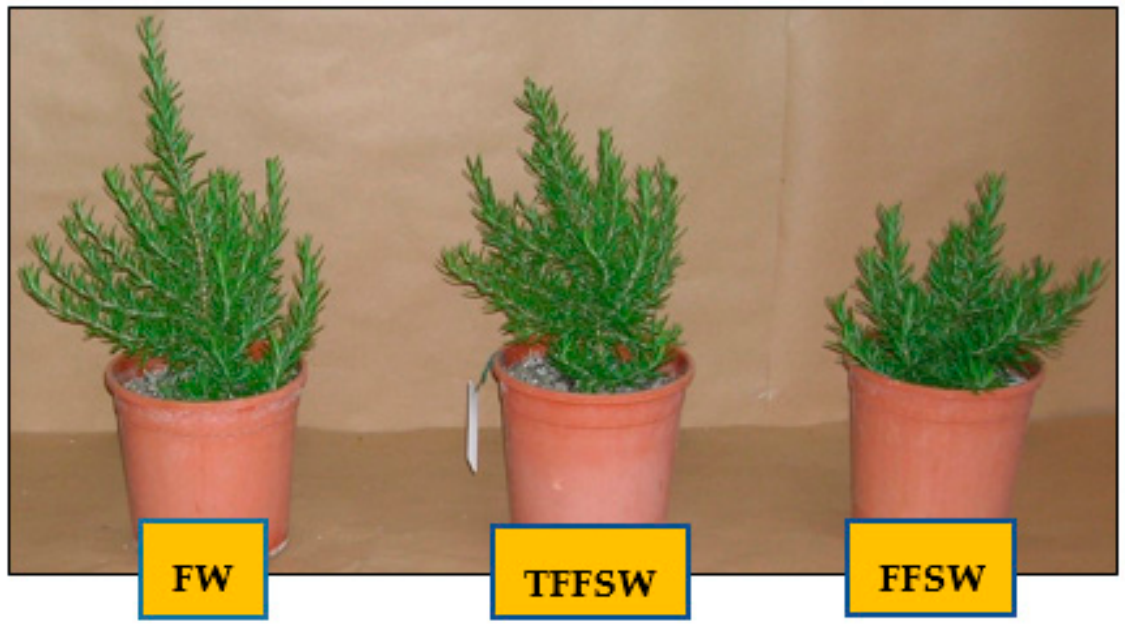

Figure 8. A view of the effect of source of irrigation water on morphological and aesthetic parameters of rosemary plants.

When comparing the types of habitus of rosemary plants, it was found that erect plants were significantly taller than prostate plants. All interactions between the two main factors had significant effects on plant height. The highest average values of plant height were obtained at FW-by-erect plant and TFFSW-by-erect plant interactions. On the contrary, the lowest average value of plant height was recorded at the FFSW-by-prostrate plant interaction.

Significant differences in plant diameter were found with respect to both main factors. Plant diameter reached the highest average values in FW- and TFFSW-irrigated plants and in rosemary plants with an erect habit (Figure 8). Similar to the plant height result, the highest values of plant diameter were recorded at FW-by-erect plant and TFFSW-by-erect plant interactions. The ratio between plant height and diameter was not significantly influenced by the source of irrigation water. In contrast, the two rosemary accessions showed significant differences for this parameter with values which ranged from 0.57 (RSM_2) to 0.72 (RSM_1). The lowest average value of this ratio was observed at the FFSW-by-prostate plant interaction.

Differences in the number of primary and secondary branches per plant were found to be significant with respect to source of irrigation water and plant habitus. In particular, the highest average values for both these morphological parameters were recorded in FW- and TFFSW-irrigated plants compared to FFSW-irrigated plants. Similar to the previous results, the irrigation water-by-plant habitus interaction effect highlights the fact that, at $\mathrm{IW}_{1}$ and $\mathrm{IW}_{2}, \mathrm{PH}_{1}$ obtained the highest average values of number of primary and secondary branches per plant compared to other combinations.

The number of leaves per plant was significantly affected by irrigation water and plant habitus and was found to be 11.44, on average, for the two accessions. The maximum number of leaves per plant was recorded for FW- and TFFSW-irrigated plants. However, in contrast with the results of other morphological parameters, rosemary plants with a prostate habit produced the maximum values (13.94), on average, for number of leaves per plant. Furthermore, prostate plants showed the higher values when interacting with the three sources of irrigation water compared to erect plants.

With regard to aesthetic parameters in the study, the two main factors significantly affected the general appearance of the rosemary plants in terms of visual quality. More specifically, FW- and TFFSW-irrigated plants showed higher average scores for visual quality with respect to FFSW-irrigated plants (Figure 8). Greater variability was observed, instead, between the two rosemary accessions. 
The plants with an erect habit had, on average, the best visual quality performance (5.17) during the test period. Finally, erect plants exhibited the highest visual quality scores when combined with the three sources of irrigation water.

Our results highlight the fact that FW- and TFFSW-irrigated plants showed greater growth and better general appearance in comparison with FFSW-irrigated plants. This fact could be mainly explained by the different trace metals levels in the three sources of irrigation water in this study. In fact, the higher trace metals levels in FFSW with respect to FW and TFFSW probably produced adverse effects on plant growth and reduced the visual quality of the rosemary plants.

The authors of [67] reported that trace elements are highly persistent and can interact with roots by adsorption or release from soil particles, increasing the risk of toxic effects on plants. It was demonstrated that heavy metal accumulation in plant tissues can produce significant physiological and biochemical responses in plants and can interfere with metabolic processes, resulting in weak plant growth, chlorosis and biomass yield depression [68].

In a study on the effects of heavy metals on the morphological characteristics of Taraxacum officinale Web, the authors [69] found that the accumulation of high amounts of different metals, such as Cd, $\mathrm{Cr}, \mathrm{Cu}, \mathrm{Fe}, \mathrm{Pb}$ and $\mathrm{Zn}$, in both shoots and roots determined significant reductions in leaf thickness and changes in cell structural organization in comparison to plants grown on unpolluted soil. On the contrary, in another study [70], it was reported that some crops, such as mint, basil, sage, lavender and rosemary, can act as hyper accumulators of heavy metals, bio-monitors and facultative metallophytes. It has been observed that heavy metal stress can enhance their essential oil percentage as well as genetic and environmental factors being able to positively influence secondary metabolite biosynthesis in several aromatic and medicinal plants [71-75].

In particular, Parra et al. [76] stated that rosemary plants can exhibit good tolerance when cultivated in heavy metal-contaminated soil and are able to translocate high heavy metal rates from roots to shoots. However, they found that high trace element concentrations in the soil and tissues of rosemary plants were related to decreases in biomass yields and inhibition of root development. These findings were also confirmed by other authors $[77,78]$ who provided a negative correlation between trace element concentrations and plant biomass and root development, highlighting that high trace elements concentration levels could determine a significant reduction in plant growth.

In our study, although irrigation with FFSW produced negative effects on plant growth and general appearance, it is worth noting that TFFSW-irrigated plants were not significantly different from FW-irrigated plants in terms of morphological and aesthetic parameters. This underlines and confirms that the reuse of TWW represents an alternative water source also when irrigating ornamental plants in various sites such as nurseries, parks, open fields and other green areas in urban environments.

A number of studies [65,79-81] have investigated the reuse of TWW on various medicinal and aromatic plants, such as basil, chamomile, mint, oregano and rosemary, in arid and semi-arid regions, focusing generally on the effects of TWW on the essential oil content and anti-oxidant properties of the plants. In particular, in a study on rosemary [81], it was found that rosemary plants continued to grow well when irrigated with urban TWW over two years and plant canopy diameter increased significantly during the test period. However, when observing the composition of the source of irrigation water used in these studies, it is possible to note an appreciable amount of macro- and micronutrients and a low heavy metal content. It is evident, therefore, that low levels of trace elements in TWW represent a fundamental condition for TWW to be able to produce positive effects on plant growth for rosemary in particular.

\subsection{Effects of Source of Irrigation Water and Type of Plant Habit on Ornamental Pepper Plants}

Data regarding the morphological, aesthetic and phenological parameters of ornamental pepper plants, under the influence of source of irrigation water and type of plant habitus, over the 2019 growing season, are shown in Table 7. 
Table 7. Morphological, aesthetic and phenological characteristics of erect and pendant plants of ornamental pepper irrigated with FW, TFFSW and FFSW.

\begin{tabular}{|c|c|c|c|c|c|c|c|c|}
\hline Treatment & $\begin{array}{l}\text { Plant Height } \\
(\mathrm{cm})\end{array}$ & $\begin{array}{l}\text { Plant Diameter } \\
\quad(\mathrm{cm})\end{array}$ & $\begin{array}{c}\text { Plant } \\
\text { Height/Diameter }\end{array}$ & $\begin{array}{l}\text { No. Fruits } \\
\text { (per Plant) }\end{array}$ & $\begin{array}{c}\text { General } \\
\text { Appearance (1-9) }\end{array}$ & $\begin{array}{l}\text { Transplanting-Beginning } \\
\text { Flowering (days) }\end{array}$ & $\begin{array}{c}\text { Transplanting-Beginning } \\
\text { Development of Fruit (days) }\end{array}$ & $\begin{array}{c}\text { Transplanting-Senescence } \\
\text { (days) }\end{array}$ \\
\hline \multicolumn{9}{|c|}{ Irrigation Water (IW) } \\
\hline $\mathrm{IW}_{1}$ & $24.22 \mathrm{a}$ & $27.54 \mathrm{a}$ & $0.84 \mathrm{~b}$ & $428.4 \mathrm{a}$ & $5.35 \mathrm{a}$ & $36.12 \mathrm{a}$ & $43.50 \mathrm{a}$ & $81.25 \mathrm{a}$ \\
\hline $\mathrm{IW}_{2}$ & $24.15 \mathrm{a}$ & $27.03 \mathrm{a}$ & $0.86 \mathrm{~b}$ & $465.5 \mathrm{a}$ & $5.18 \mathrm{a}$ & $36.57 \mathrm{a}$ & $42.88 \mathrm{a}$ & $81.76 \mathrm{a}$ \\
\hline $\mathrm{IW}_{3}$ & $22.03 \mathrm{~b}$ & $21.82 \mathrm{~b}$ & $1.01 \mathrm{a}$ & $327.5 \mathrm{~b}$ & $3.67 \mathrm{~b}$ & $30.00 \mathrm{~b}$ & $37.50 \mathrm{~b}$ & $74.02 \mathrm{~b}$ \\
\hline \multicolumn{9}{|c|}{ Plant Habitus (PH) } \\
\hline $\mathrm{PH}_{1}$ & $32.50 \mathrm{a}$ & $33.30 \mathrm{a}$ & $0.97 \mathrm{a}$ & $662.1 \mathrm{a}$ & $5.80 \mathrm{a}$ & $32.01 \mathrm{~b}$ & $38.33 \mathrm{~b}$ & $75.33 \mathrm{~b}$ \\
\hline $\mathrm{PH}_{2}$ & $14.48 \mathrm{~b}$ & $17.66 \mathrm{~b}$ & $0.84 \mathrm{~b}$ & $152.1 \mathrm{~b}$ & $3.67 \mathrm{~b}$ & $36.02 \mathrm{a}$ & $44.67 \mathrm{a}$ & $82.11 \mathrm{a}$ \\
\hline \multicolumn{9}{|c|}{$\begin{array}{c}\text { Irrigation Water } \times \\
\text { Plant Habitus }\end{array}$} \\
\hline $\mathrm{IW}_{1} \times \mathrm{PH}_{1}$ & $34.67 \mathrm{a}$ & $35.50 \mathrm{a}$ & 0.97 a & 691.4a & $6.47 \mathrm{a}$ & $32.84 \mathrm{c}$ & $40.56 \mathrm{~b}$ & $78.00 \mathrm{~b}$ \\
\hline $\mathrm{IW}_{1} \times \mathrm{PH}_{2}$ & $13.67 \mathrm{c}$ & $19.48 \mathrm{c}$ & $0.70 \mathrm{~b}$ & $165.4 \mathrm{c}$ & $4.23 \mathrm{~b}$ & $38.65 \mathrm{a}$ & $47.01 \mathrm{a}$ & $84.27 \mathrm{a}$ \\
\hline $\mathrm{IW}_{2} \times \mathrm{PH}_{1}$ & $34.20 \mathrm{a}$ & $35.76 \mathrm{a}$ & $0.95 \mathrm{a}$ & $750.5 \mathrm{a}$ & $6.43 \mathrm{a}$ & $34.14 \mathrm{~b}$ & $40.02 \mathrm{~b}$ & $77.54 \mathrm{~b}$ \\
\hline $\mathrm{IW}_{2} \times \mathrm{PH}_{2}$ & $14.23 \mathrm{c}$ & $18.40 \mathrm{c}$ & $0.77 \mathrm{~b}$ & $180.5 \mathrm{c}$ & $3.93 \mathrm{~b}$ & $38.21 \mathrm{a}$ & $47.54 \mathrm{a}$ & $84.88 \mathrm{a}$ \\
\hline $\mathrm{IW}_{3} \times \mathrm{PH}_{1}$ & $28.63 \mathrm{~b}$ & $28.53 \mathrm{~b}$ & $1.00 \mathrm{a}$ & $544.4 \mathrm{~b}$ & $4.50 \mathrm{~b}$ & $28.00 \mathrm{~d}$ & $35.02 \mathrm{c}$ & $70.00 \mathrm{c}$ \\
\hline $\mathrm{IW}_{3} \times \mathrm{PH}_{2}$ & $15.43 \mathrm{c}$ & $15.10 \mathrm{~d}$ & $1.02 \mathrm{a}$ & $110.5 \mathrm{c}$ & $2.83 \mathrm{~b}$ & $32.00 \mathrm{c}$ & $39.81 \mathrm{~b}$ & $77.21 \mathrm{~b}$ \\
\hline
\end{tabular}

Means followed by the same letter are not significantly different for $p \leq 0.05$ according to the test of Tukey. 
All the characteristics tested were significantly affected by irrigation water and plant habitus. Furthermore, the irrigation water-by-plant habitus interaction was significant for each parameter in the study. In particular, FW- and TFFSW-irrigated plants exhibited higher growth than FFSW-irrigated plants during the test period.

Plant height ranged from 32.50 (erect plants) to $14.48 \mathrm{~cm}$ (pendant plants), on average. When considering the source of irrigation water, it was found that FW-and TFFSW-irrigated plants were significantly taller than FFSW-irrigated plants (Figure 9).

Furthermore, regarding the interaction effects between the main factors, the highest average values for plant height were observed in FW-by-erect plant and TFFSW-by-erect plant interactions. On the contrary, the lowest average value of plant height was recorded when the pendant habit factor interacted with each of the three sources of irrigation water.

Plant diameter showed significant differences with respect to the main factors. The highest average values of plant diameter were found in FW- and TFFSW-irrigated plants and in erect plants (Figure 9). When considering, instead, all the interactions, the FW-by-erect plant and TFFSW-by-erect plant interactions had the highest values of plant diameter.

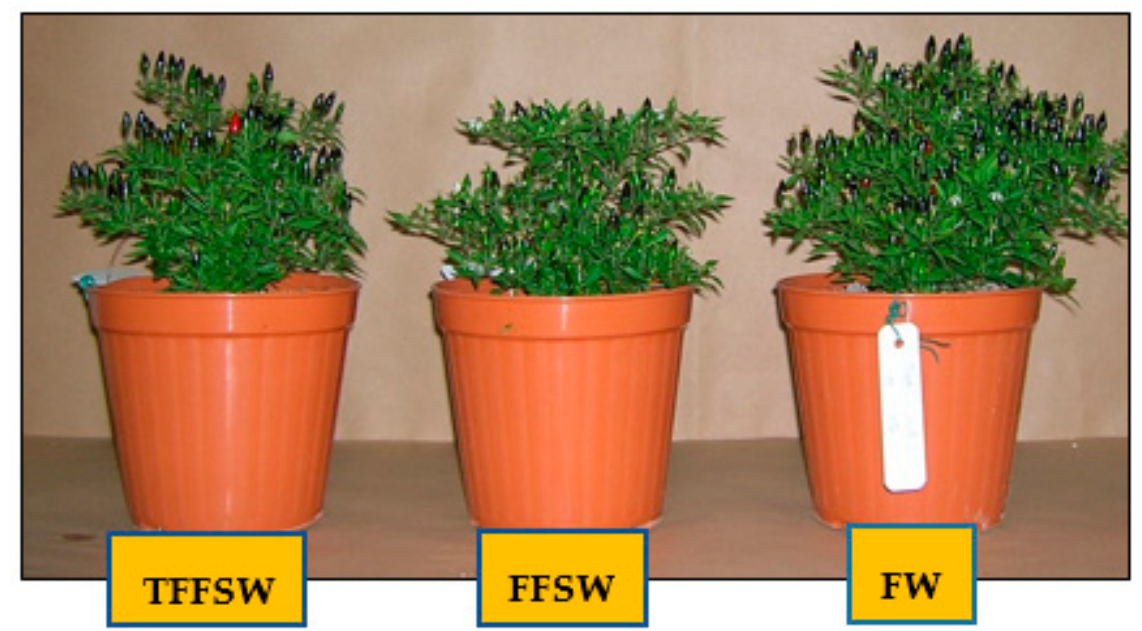

Figure 9. A view of the effect of source of irrigation water on the morphological and aesthetic parameters of ornamental pepper plants.

The ratio between plant height and diameter was significantly affected by the two main factors. More specifically, no significant differences were found between FW- and TFFSW-irrigated plants; in contrast, FFSW-irrigated plants and erects plants exhibited the highest average values. When considering the interaction effects, no significant differences were found for this parameter except for IW1-by-PH2 and IW2-by-PH2 interactions.

The number of fruits per plant was significantly affected by irrigation water and plant habitus and was found to be 407.12, on average, for the two pepper varieties. However, the number of fruits ranged from 662.10 (erect plants) to 152.15 (pendant plants), on average. Similar to the previous results, FWand TFFSW-irrigated plants obtained maximum values for number of fruits per plant. Furthermore, the erect plants showed higher values when interacting with the three sources of irrigation water compared to pendant plants.

With regard to the general appearance of the ornamental pepper plants, FW- and TFFSW-irrigated plants showed higher average values for visual quality compared to FFSW-irrigated plants. Erect plants had, on average, the best visual quality performance (5.80), while the pendant plants obtained the lowest value (3.67). Erect plants exhibited the highest visual quality scores when combined with FW and TFFSW only.

Finally, irrigation water and plant habitus had a significant effect on ornamental pepper plant phenology. In particular, the number of days between transplanting and beginning of flowering 
was higher in FW- and TFFSW-irrigated plants (36 days, on average) than in FFSW-irrigated plants. Beginning of fruit development occurred six days later in FW- and TFFSW-irrigated plants than in FFSW-irrigated plants. On the contrary, senescence occurred seven days earlier in FFSW-irrigated plants. In general, FW- and TFFSW-irrigated plants completed their growth cycle within 81 days, whilst the growth cycle length of FFSW-irrigated plants was found to be close to 74 days, on average. It is worth noting that the main phenological stages in the study occurred earlier in erect plants with respect to pendant plants. The significance found for the irrigation water-by-plant habitus interaction instead highlights the fact that, for each source of irrigation water, the differences in the growth stages were consistent with the effects of the main two factors.

Our findings demonstrate that FW- and TFFSW-irrigated plants exhibited higher growth and showed a better general appearance in comparison with FFSW-irrigated plants. Similar to the results of rosemary plants, the different trace metal concentrations in the three sources of irrigation water significantly affected the behavior of ornamental pepper plants during the tests. Hence, the lower trace metal concentrations in FW and TFFSW favored plant growth and improved, in general, the aesthetic characteristics of ornamental pepper plants.

The effects of trace metals, contained in irrigation water, on the morphological and aesthetic characteristics of ornamental pepper have been not investigated in the literature. Due to this fact, it was not possible to compare our findings with those of other studies. Additionally, few studies are available which focus on the use of TWW in ornamental pepper cultivation as affecting growth and fruit quality. In a study carried out in Crete [66], it was found that TWW application increased plant height and plant biomass compared with FW-irrigated plants of pepper, while the addition of fertigation increased fruit number in both FW- and TWW-irrigated plants, but with a decreasing average fruit weight for TWW application. This was in agreement with previous studies on cucumber and tomato crops when irrigating with FW and TWW [34,82]. In another study on the effect of different irrigation levels with different qualities of water on the cultivation of pepper [83], it was reported that TWW provided nutrients for the plants and determined an increase in plant growth.

In our study, although the chemical and microbiological composition of TFFSW differed greatly from that of FW (Table 5), TFFSW-irrigated plants were not significantly different from FW-irrigated plants in terms of morphological, aesthetic and phenological parameters. This fact could be explained by considering the agronomic management of pepper plants during the tests. In the FW-irrigated pots, we managed the pepper plants using fertigation during the crop cycle; in the TFFSW-irrigated pots, we exploited the nutrient content in this source of irrigation water to integrate the N, P and K requirements for ornamental pepper. At the outflow of the VSSFs CW unit, the N, P and K average concentrations were found to meet the plant's requirements. TFFSW was a source of nutrients and, in particular, of N, P and K, therefore its use highlights the fact that TWW irrigation also provides combined fertilization for ornamental pepper plants. It is worth noting that the trace metals and PAH content in the TFFSW was within the threshold values for Italian Legislative Decree 152/2006 regarding the reuse of TWW for irrigation purposes, as well as other chemical and microbiological parameters. These results confirm that TWW irrigation, such as TFFSW, can decrease or even remove the need for mineral fertilization whilst maintaining a high quantitative and qualitative performance of plants. This concept was previously confirmed also for other horticultural crops $[34,66,82,84]$ and currently should be used by farmers due to the evident economic and environmental benefits with respect to the common management of these crops. In fact, as TWW is an alternative source of water to FW for crop irrigation, it is possible to suppose that the use of TWW of different origin represents a sustainable way to manage the irrigation and fertilization of a number of crops, such as rosemary or ornamental pepper, in areas with prolonged periods of water shortages.

\section{Conclusions}

The results of this case study carried out on a VSSFs CW are promising and highlight good efficiency of this system in view of treating first-flush stormwater and reusing treated stormwater for irrigation 
purposes in Sicilian semi-arid environments. Furthermore, the application of a VSSFs CW in urban and industrial areas could led to evident ecological benefits due to the fact that a VSSFs significantly improves the quality of this type of wastewater and reduces pollutant mass loads, preventing the pollution of receiving water bodies and soil. Furthermore, the use of treated wastewater in irrigated agriculture could determine certain agronomical advantages, mainly consisting of large freshwater and fertilizer savings in the management of crops. In this study, the removal efficiency of organic matter, nutrients, trace metals and PAHs was satisfactory, although pollutant concentrations at the inlet of the VSSFs were reasonably low during the two testing periods. This probably depended on the performance of the pretreatment system used and the wastewater volumes. In the VSSFs CW, the role of the two macrophytes was essential for the treatment of first-flush stormwater. The polyculture system, in the CW unit, consisting of a mixture of common reed and giant reed, contributed, in fact, to the overall performance of the VSSFs and to the removal of dissolved organic compounds and nutrients in particular. For both ornamental pepper and rosemary, TFFSW-irrigated plants were not significantly different from FW-irrigated plants in terms of morphological and aesthetic parameters. This means that TFFSW could be used in the irrigation of ornamental plants in place of FW. However, this is possible only when the chemical and microbiological composition of TFFSW fully respects national legislation requirements. In fact, an average trace metal concentration which is higher than required could produce adverse effects on plant growth and reduce the visual quality of the plants, for example.

Finally, further research is required to evaluate VSSFs performance over a longer period of time and to improve the removal efficiency of specific contaminants. The use of hybrid CWs, for example, may increase the removal efficiency of trace metals, PAHs and pathogens and allow treated stormwater to be more easily discharged into soils and water bodies. For ornamental pepper and rosemary, the effects of TFFSW on biomass yield and qualitative characteristics in the long term require evaluation.

Supplementary Materials: The following are available online at http:/www.mdpi.com/2073-4441/12/9/2542/s1, Table S1: Average monthly air temperature and rainfall during a multi-year average (2009-2019) in ExpA_1. Table S2: Average monthly air temperature during a multi-year average (2009-2019) in ExpA_2.

Author Contributions: Conceptualization, T.T. and S.L.B.; methodology, T.T. and S.L.B.; software, M.L. and G.V.; validation, C.L. and M.L.; formal analysis, T.T., M.L. and G.V.; investigation, G.V., M.L., S.L.B. and C.L.; resources, T.T. and S.L.B.; data curation, M.L., G.V. and C.L.; writing-original draft preparation, M.L. and C.L.; writing-review and editing, M.L. and G.V.; visualization, M.L. and C.L.; supervision, T.T. and S.L.B.; project administration, C.L.; funding acquisition, C.L. All authors have read and agreed to the published version of the manuscript.

Funding: This research was funded by the Sicilian Regional Ministry of Agriculture and Food Resources (Italy), grant number: D71D04000000008.

Acknowledgments: The authors would like to thank the Sicilian Regional Ministry of Food and Agricultural Resources funding the "Tecnologie innovative per l'impiego di acque non convenzionali e prevenzione della desertificazione" research project. A special thanks goes to Lucie Branwen Hornsby for her linguistic assistance.

Conflicts of Interest: The authors declare no conflict of interest. The funders had no role in the design of the study; in the collection, analyses, or interpretation of data; in the writing of the manuscript, or in the decision to publish the results.

\section{References}

1. Davis, B.S.; Birch, G.F. Catchment-wide assessment of the cost-effectiveness of stormwater remediation measures in urban areas. Environ. Sci. Policy 2009, 12, 84-91. [CrossRef]

2. Wei, Z.; Simin, L.; Fengbing, T. Characterization of urban runoff pollution between dissolved and particulate phases. Sci. World. J. 2013, 964737, 1-6. [CrossRef] [PubMed]

3. Malaviya, P.; Singh, A. Constructed wetlands for management of urban stormwater runoff. Crit. Rev. Environ. Sci. Technol. 2012, 42, 2153-2214. [CrossRef]

4. Lee, J.H.; Bang, K.W.; Ketchum, L.H.; Choe, J.S.; Yu, M.J. First flush analysis of urban storm runoff. Sci. Total Environ. 2002, 293, 163-175. [CrossRef] 
5. Thornton, R.C.; Saul, A.J. Some quality characteristics of combined sewer flows. J. Inst. Public Health Eng. 1986, 14, 35-38.

6. Zuraini, N.A.; Alias, N.; Yusof, Z.M.; Hanapi, M.N.; Harun, S. First flush analysis of urban stormwater runoff from an urban catchment in Johor, Malaysia. MATEC Web Conf. 2018, 250, 06014. [CrossRef]

7. Mamun, A.A.; Shams, S.; Nuruzzaman, M. Review on uncertainty of the first-flush phenomenon in diffuse pollution control. Appl. Water Sci. 2020, 10, 53. [CrossRef]

8. Ávila, C.; Salas, J.J.; Martín, I.; Aragón, C.; García, J. Integrated treatment of combined sewer wastewater and stormwater in a hybrid constructed wetland system in southern Spain and its further reuse. Ecol. Eng. 2013, 50, 13-20. [CrossRef]

9. Zhang, Q.; Wang, X.; Hou, P.; Wan, W.; Ren, Y.; Ouyang, Z.; Yang, L. The temporal changes in road stormwater runoff quality and the implications to first flush control in Chongqing, China. Environ. Monit. Assess. 2013, 185, 9763-9775. [CrossRef]

10. Taebi, A.; Droste, R.L. First flush pollution load of urban stormwater runoff. J. Environ. Eng. Sci. 2004, 3, 301-309. [CrossRef]

11. Hathaway, J.M.; Tucker, R.S.; Spooner, J.M.; Hunt, W.F. A traditional analysis of the first flush effect for nutrients in stormwater runoff from two small urban catchments. Water Air Soil Pollut. 2012, 223, 5903-5915. [CrossRef]

12. Sansalone, J.J.; Cristina, C.M. First flush concepts for suspended and dissolved solids in small impervious watersheds. J. Environ. Eng. 2004, 130, 1301-1314. [CrossRef]

13. Lee, J.H.; Bang, K.W. Characterization of urban stormwater runoff. Water Res. 2000, 34, 1772-1780. [CrossRef]

14. McCarthy, D.T. A traditional first flush assessment of E. coli in urban stormwater runoff. Water Sci. Technol. 2009, 60, 2749-2757. [CrossRef] [PubMed]

15. Chow, M.F.; Yusop, Z. Sizing first flush pollutant loading of stormwater runoff in tropical urban catchments. Environ. Earth Sci. 2014, 72, 4047-4058. [CrossRef]

16. Gupta, K.; Saul, A.J. Specific relationships for the first flush load in combined sewer flows. Water Res. 1996, 30, 1244-1252. [CrossRef]

17. Li, L.Q.; Yin, C.Q.; He, Q.C.; Kong, L.L. First flush of storm runoff pollution from an urban catchment in China. J. Environ. Sci. 2007, 19, 295-299. [CrossRef]

18. Huang, J.; Du, P.; Ao, C.; Lei, M.; Zhao, D.; Ho, M.; Wang, Z. Characterization of surface runoff from a subtropics urban catchment. J. Environ. Sci. 2007, 19, 148-152. [CrossRef]

19. Cho, J.H.; Lee, J.H. Stormwater runoff characteristics and effective management of nonpoint source pollutants from a highland agricultural region in the lake Soyang watershed. Water 2017, 9, 784. [CrossRef]

20. Li, D.; Wan, J.; Ma, Y.; Wang, Y.; Huang, M.; Chen, Y. Stormwater runoff pollutant loading distributions and their correlation with rainfall and catchment characteristics in a rapidly industrialized city. PLoS ONE 2015, 10, e0118776. [CrossRef]

21. Xu, H.; Zhang, Y.; Zhu, X.; Zheng, M. Effects of rainfall-runoff pollution on eutrophication in coastal zone: A case study in Shenzhen Bay, southern China. Hydrol. Res. 2019, 50, 1062-1075. [CrossRef]

22. Liu, W.; Wang, C.; Yu, Y.; Chen, Y.; Du, L.; Qu, X.; Peng, W.; Zhang, M.; Gui, C. Effect of urban stormwater road runoff of different land use types on an urban river in Shenzhen, China. Water 2019, 11, 2545. [CrossRef]

23. Vymazal, J. Constructed wetlands for wastewater treatment: Five decades of experience. Environ. Sci. Technol. 2011, 45, 61-69. [CrossRef]

24. Stefanakis, A.I. The role of constructed wetlands as green infrastructure for sustainable urban water management. Sustainability 2019, 11, 6981. [CrossRef]

25. Vymazal, J. Removal of nutrients in various types of constructed wetlands. Sci. Total Environ. 2007, 380, 48-65. [CrossRef] [PubMed]

26. Leto, C.; Tuttolomondo, T.; La Bella, S.; Leone, R.; Licata, M. Growth of Arundo donax L. and Cyperus alternifolius $\mathrm{L}$. in a horizontal subsurface flow constructed wetland using pre-treated urban wastewater-A case study in Sicily (Italy). Desalin. Water Treat. 2013, 251, 7447-7459. [CrossRef]

27. Khan, S.; Ahmad, I.; Shah, M.T.; Rehman, S.; Khaliq, A. Use of constructed wetland for the removal of heavy metals from industrial wastewater. J. Environ. Manag. 2009, 90, 3451-3457. [CrossRef]

28. Sgroi, M.; Pellissari, C.; Roccaro, P.; Sezerino, P.H.; García, J.; Vagliasindi, F.G.A.; Ávila, C. Removal of organic carbon, nitrogen, emerging contaminants and fluorescing organic matter in different constructed wetland configurations. Chem. Eng. J. 2018, 332, 619-627. [CrossRef] 
29. Knight, R.L. Wildlife habitat and public use benefits of treatment wetlands. Water Sci. Technol. 1997, 35, 35-43. [CrossRef]

30. Choi, J.Y.; Maniquiz-Redillas, M.C.; Hong, J.S.; Lee, S.Y.; Kim, L.H. Comparison of the treatment performance of hybrid constructed wetlands treating stormwater runoff. Water Sci. Technol. 2015, 72, 2243-2250. [CrossRef]

31. Ventura, D.; Barbagallo, S.; Consoli, M.; Ferrante, M.; Milani, M.; Licciardello, F.; Cirelli, G.L. On the performance of a pilot hybrid constructed wetland for stormwater recovery in Mediterranean climate. Water Sci. Technol. 2019, 79, 1051-1059. [CrossRef] [PubMed]

32. Adyel, T.M.; Oldham, C.E.; Hipsey, M.R. Stormwater nutrient attenuation in a constructed wetland with alternating surface and subsurface flow pathways; event to annual dynamics. Water Res. 2016, 107, 66-82. [CrossRef] [PubMed]

33. Carleton, J.N.; Grizzard, T.J.; Godrej, A.N.; Post, H.E. Factors affecting the performance of stormwater treatment wetlands. Water Res. 2001, 35, 1552-1562. [CrossRef]

34. Licata, M.; La Bella, S.; Virga, G.; Leto, C.; Tuttolomondo, T. Management of irrigation water and nutrient demands of tomato (Lycopersicon esculentum Mill.) using urban treated wastewater from a pilot-scale horizontal subsurface flow system constructed wetland in Sicily (Italy). Desalin. Water Treat. 2017, 73, 422-439. [CrossRef]

35. La Bella, S.; Tuttolomondo, T.; Leto, C.; Bonsangue, G.; Leone, R.; Virga, G.; Licata, M. Pollutant removal efficiency of a pilot-scale Horizontal Subsurface Flow in Sicily (Italy) planted with Cyperus alternifolius L. and Typha latifolia L. and reuse of treated wastewater for irrigation of Arundo donax L. for pellet production-Results of two-year tests under Mediterranean climatic conditions. Desalin. Water Treat. 2016, 57, 22743-22763. [CrossRef]

36. Cirelli, G.L.; Consoli, S.; Di Grande, V.; Milani, M.; Toscano, A. Subsurface constructed wetlands for wastewater treatment and reuse in agriculture: Five years of experiences in Sicily, Italy. Water Sci. Technol. 2007, 56, 183-191. [CrossRef]

37. Licata, M.; Tuttolomondo, T.; Leto, C.; La Bella, S.; Virga, G. The use of constructed wetlands for the treatment and reuse of urban wastewater for the irrigation of two warm-season turfgrass species under Mediterranean climatic conditions. Water Sci. Technol. 2017, 76, 459-470. [CrossRef] [PubMed]

38. Milani, M.; Consoli, S.; Marzo, A.; Pino, A.; Randazzo, C.; Barbagallo, S.; Cirelli, G.L. Treatment of winery wastewater with a multistage constructed wetland system for irrigation reuse. Water 2020, 12, 1260. [CrossRef]

39. Licata, M.; Gennaro, M.C.; Tuttolomondo, T.; Leto, C.; La Bella, S. Research focusing on plant performance in constructed wetlands and agronomic application of treated wastewater-A set of experimental studies in Sicily (Italy). PLoS ONE 2019, 14, e0219445. [CrossRef]

40. Barbagallo, S.; Barbera, A.C.; Cirelli, G.L.; Milani, M.; Toscano, A. Reuse of constructed wetland effluents for irrigation of energy crops. Water Sci. Technol. 2014, 70, 1465-1472. [CrossRef]

41. Kottek, M.; Grieser, J.; Beck, C.; Rudolf, B.; Rubel, F. World map of the Köppen-Geiger climate classification updated. Meteorol. Z. 2006, 15, 259-263. [CrossRef]

42. APAT; CNR-IRSA. Metodi Analitici per le Acque, 1st ed.; APAT: Rome, Italy, 2003; pp. 115-696.

43. VV.AA. American Public Health Association, Standard Methods for the Examination of Water and Wastewater, 23rd ed.; APHA: Washington, DC, USA, 2017; pp. 9010-9230.

44. Kadlec, R.H.; Knight, R.L.; Vymazal, J.; Brix, H.; Cooper, P.; Haberl, R. Constructed Wetlands for Pollution Control: Processes, Performance, Design and Operation, 1st ed.; IWA Publishing: London, UK, 2000; pp. 17-90.

45. Yadav, R.K.; Sangwan, R.S.; Sabir, F.; Srivastava, A.K.; Sangwan, N.S. Effect of prolonged water stress on specialized secondary metabolites, peltate glandular trichomes, and pathway gene expression in Artemisia annua L. Plant Physiol. Bioch. 2014, 74, 70-83. [CrossRef]

46. Lancashire, P.D. A uniform decimal code for growth stages of crops and weeds. Ann. Appl. Biol. 1991, 119, 561-601. [CrossRef]

47. Servizio Informativo Agrometeorologico Siciliano. Available online: www.sias.regione.sicilia.it (accessed on 11 August 2020).

48. Kurniadie, D. Wastewater treatment using vertical subsurface flow constructed wetland in Indonesia. Am. J. Environ. Sci. 2011, 7, 15-19. [CrossRef]

49. Gerardi, M.H. Alkalinity and pH. In Nitrification and Denitrification in Activated Sludge Processes, 1st ed.; John Wiley and Sons. Inc.: New York, NY, USA, 2002; pp. 109-114. 
50. Abdelhakeem, S.G.; Aboulroos, S.A.; Kamel, M.M. Performance of a vertical subsurface flow constructed wetland under different operational conditions. J. Adv. Res. 2016, 7, 803-814. [CrossRef]

51. Zurita, F.; De Anda, J.; Belmont, M.A. Treatment of domestic wastewater and production of commercial flowers in vertical and horizontal sub-surface flow constructed wetlands. Ecol. Eng. 2009, 35, 861-869. [CrossRef]

52. Kadlec, R.H.; Wallace, S.D. Treatment Wetlands, 2nd ed.; CRC Press Taylor \& Francis Group: Boca Raton, FL, USA, 2009; pp. 228-236.

53. Karathanasis, A.D.; Potter, C.L.; Coyne, M.S. Vegetation effects on fecal bacteria, BOD, and suspended solid removal in constructed wetland treating domestic wastewater. Ecol. Eng. 2003, 20, 157-169. [CrossRef]

54. Chen, Z.M.; Chen, B.; Zhou, J.B.; Li, Z.; Zhou, Y.; Xi, X.R.; Lin, C.; Chen, C.Q. A vertical subsurface-flow constructed wetland in Beijing. Commun. Nonlinear Sci. Number Simul. 2008, 13, 1986-1997. [CrossRef]

55. Meuleman, A.F.M.; van Logtestijn, R.; Rijs, G.B.J.; Verhoeven, J.T.A. Water and mass budgets of a vertical-flow constructed wetland used for wastewater treatment. Ecol. Eng. 2003, 20, 31-44. [CrossRef]

56. Arias, C.A.; Brix, H.; Marti, E. Recycling of treated effluents enhances removal of total nitrogen in vertical flow constructed wetlands. J. Environ. Sci. Health 2005, 40, 1431-1443. [CrossRef]

57. Prochaska, C.A.; Zouboulis, A.I. Removal of phosphates by pilot vertical-flow constructed wetlands using a mixture of sand and dolomite as substrate. Ecol. Eng. 2006, 26, 293-303. [CrossRef]

58. Birch, G.F.; Matthai, C.; Fazeli, M.S.; Suh, J.Y. Efficiency of a constructed wetland in removing contaminants from stormwater. Wetlands 2004, 24, 459-466. [CrossRef]

59. Lee, B.H.; Scholz, M. What is the role of Phragmites australis in experimental constructed wetland filters treating urban runoff? Ecol. Eng. 2006, 29, 87-95. [CrossRef]

60. Schmitt, N.; Wanko, A.; Laurent, J.; Bois, P.; Molle, P.; Mosé, R. Constructed wetlands treating stormwater from separate sewer networks in a residential Strasbourg urban catchment area: Micropollutant removal and fate. J. Environ. Chem. Eng. 2015, 3, 2816-2824. [CrossRef]

61. Terzakis, S.; Fountoulakis, M.S.; Georgaki, I.; Albantakis, D.; Sabathianakis, I.; Karathanasis, A.D.; Kalogerakis, N.; Manios, T. Constructed wetlands treating highway runoff in the central Mediterranean region. Chemosphere 2008, 72, 141-149. [CrossRef] [PubMed]

62. Alsghayer, R.; Salmiaton, A.; Mohammad, A.; Idris, A.; Ishak, C.F. Removal efficiencies of constructed wetland planted with Phragmites and Vetiver in treating synthetic wastewater contaminated with high concentration of PAHs. Sustainability 2020, 12, 3357. [CrossRef]

63. Brix, H. Do macrophytes play a role in constructed treatment wetlands? Water Sci. Technol. 1997, 35, 11-17. [CrossRef]

64. Vymazal, J. Removal of enteric bacteria in constructed treatment wetlands with emergent macrophytes: A review. J. Environ. Sci. Health 2005, 40, 1355-1367. [CrossRef]

65. Bernstein, N.; Chaimovitch, D.; Dudai, N. Effect of irrigation with secondary treated effluent on essential oil, antioxidant activity, and phenolic compounds in oregano and rosemary. Agron. J. 2009, 101, 1-10. [CrossRef]

66. Dagianta, E.; Goumas, D.; Manios, T.; Tzortzakis, N. The use of treated wastewater and fertigation in greenhouse pepper crop as affecting growth and fruit quality. J. Water Reuse Desal. 2014, 4, 92-99. [CrossRef]

67. Rosselli, W.; Rossi, M.; Sasu, I. Cd, Cu and Zn contents in the leaves of Taraxacum officinale. For. Snow Landsc. Res. 2006, 80, 361-366.

68. Lopareva-Pohu, A.; Verdin, A.; Garçon, G.; Sahraoui, A.L.; Pourrut, B.; Debiane, D.; Waterlot, C.; Laruelle, F.; Bidar, G.; Douay, F.; et al. Influence of fly ash aided phytostabilisation of $\mathrm{Pb}, \mathrm{Cd}$ and $\mathrm{Zn}$ highly contaminated soils on Lolium perenne and Trifolium repens metal transfer and physiological stress. Environ. Pollut. 2011, 159, 1721-1729. [CrossRef] [PubMed]

69. Bini, C.; Wahsha, M.; Fontana, S.; Maleci, L. Effects of heavy metals on morphological characteristics of Taraxacum officinale Web growing on mine soils in NE Italy. J. Geochem. Explor. 2012, 132, 101-108. [CrossRef]

70. Pandey, J.; Verma, R.K.; Singh, S. Suitability of aromatic plants for phytoremediation of heavy metals contaminated areas: A review. Int. J. Phytoremediat. 2019, 405-418. [CrossRef]

71. Tuttolomondo, T.; Leto, C.; Leone, R.; Licata, M.; Virga, G.; Ruberto, G.; Napoli, E.M.; La Bella, S. Essential oil characteristics of wild Sicilian oregano populations in relation to environmental conditions. J. Essent. Oil Res. 2014, 26, 210-220. [CrossRef] 
72. Tuttolomondo, T.; Dugo, G.; Leto, C.; Cicero, N.; Tropea, A.; Virga, G.; Leone, R.; Licata, M.; La Bella, S. Agronomical and chemical characterisation of Thymbra capitata (L.) Cav. biotypes from Sicily, Italy. Nat. Prod. Res. 2015, 29, 1289-1299. [CrossRef]

73. Saija, A.; Speciale, A.; Trombetta, D.; Leto, C.; Tuttolomondo, T.; La Bella, S.; Licata, M.; Virga, G.; Bonsangue, G.; Gennaro, M.C.; et al. Phytochemical, ecological and antioxidant evaluation of wild Sicilian thyme: Thymbra capitata (L.) Cav. Chem. Biodivers. 2016, 13, 1641-1655. [CrossRef]

74. Napoli, E.M.; Siracusa, L.; Saija, A.; Speciale, A.; Trombetta, D.; Tuttolomondo, T.; La Bella, S.; Licata, M.; Virga, G.; Leone, R.; et al. Wild Sicilian rosemary: Phytochemical and morphological screening and antioxidant activity evaluation of extracts and essential oils. Chem. Biodivers. 2015, 12, 1075-1094. [CrossRef]

75. Tuttolomondo, T.; Dugo, G.; Ruberto, G.; Leto, C.; Napoli, E.M.; Potortì, A.G.; Fede, M.R.; Virga, G.; Leone, R.; D'Anna, E.; et al. Agronomical evaluation of Sicilian biotypes of Lavandula stoechas L. spp. stoechas and analysis of the essential oils. J. Essent. Oil Res. 2015, 27, 115-124. [CrossRef]

76. Parra, A.; Zornoza, R.; Conesa, E.; Gomez-Lopez, M.D.; Faz, A. Seedling emergence, growth and trace elements tolerance and accumulation by Lamiaceae species in a mine soil. Chemosphere 2014, 113, 132-140. [CrossRef]

77. Shi, X.; Zhang, X.; Chen, G.; Chen, Y.; Wang, L.; Shan, Z. Seedling growth and metal accumulation of selected woody species in copper and lead/zinc mine tailings. J. Environ. Sci. 2011, 23, 266-276. [CrossRef]

78. Zheljazkov, V.D.; Craker, L.E.; Xing, B. Effects of $\mathrm{Cd}, \mathrm{Pb}$, and $\mathrm{Cu}$ on growth and essential oil contents in dill, peppermint, and basil. Environ. Exp. Bot. 2006, 58, 9-16. [CrossRef]

79. Khalifa, R.M.; Abouziena, H.F.; El-Mergawi, R.A.; Youssef, A.A. Nutritional status of some aromatic plants grown to produce volatile oils under treated municipal wastewater irrigation. Aust. J. Basic App. Sci. 2011, 5, 2999-3007.

80. Darvishi, H.H.; Manshouri, M.; Sedghi, H.; Jahromi, S.H.M. Irrigation influence by treated domestic wastewater instead of agronomical water on essential oil yield of basil (Ocimum basilicum L.). Afr. J. Microbiol. Res. 2010, 4, 475-479.

81. Bozdogan, E. Re-use of treated wastewater for irrigation of Rosmarinus officinalis L. J. Hortic. Sci. Biotech. 2015, 90, 711-714. [CrossRef]

82. Manios, T.; Papagrigoriou, I.; Daskalakis, G.; Sabathianakis, I.; Terzakis, S.; Maniadakis, K.; Markakis, G. Evaluation of primary and secondary treated and disinfected wastewater irrigation of tomato and cucumber plants under greenhouse conditions, regarding growth and safety considerations. Water Environ. Res. 2006, 78, 797-804. [CrossRef]

83. Silva, V.F.; de Lima, V.L.A.; Nascimento, E.C.; de Andrade, L.O.; Oliveira, H.; Ferreira, A.C. Effect of different irrigation levels with different qualities of water and organic substrates on cultivation of pepper. Afr. J. Agric. Res. 2016, 11, 1373-1380. [CrossRef]

84. Licata, M.; La Bella, S.; Leto, C.; Virga, G.; Leone, R.; Bonsangue, G.; Tuttolomondo, T. Reuse of urban-treated wastewater from a pilot-scale horizontal subsurface flow system in Sicily (Italy) for irrigation of Bermudagrass (Cynodon dactylon (L.) Pers.) turf under Mediterranean climatic conditions. Desalin. Water Treat. 2016, 57, 23343-23364. [CrossRef]

(C) 2020 by the authors. Licensee MDPI, Basel, Switzerland. This article is an open access article distributed under the terms and conditions of the Creative Commons Attribution (CC BY) license (http://creativecommons.org/licenses/by/4.0/). 